\title{
BONECAS, ROBÔS, NARCISOS E FETICHES: O ESQUECIMENTO DE SI E A DESUMANIZAÇÃO DO OUTRO
}

PABLO PETIT PASSOS SÉRVIO

Universidade Federal do Maranhão

RESUMO Inspirado nas Mnemosynes de Warburg, construo uma prancha na qual ponho algumas imagens de diversas categorias (cinema, pinturas, performances artísticas etc.) para dialogar com as imagens da campanha publicitária Melissa Loverobots. Enfrento debates sobre uma subjetividade fetichista e narcisista, estimulada pela sociedade de consumo, e reflito sobre um ideal de identidade associado à imagem do corpo. Questiono, ainda, a relação narcisista e fetichista que podemos estabelecer com tecnologias digitais, em especial, com os chamados robôs e redes sociais. Concluo com a defesa de processos educacionais que questionem tais fenômenos e promovam experiências alternativas.

Palavras-chave: Fetichismo. Narcisismo. Cultura Visual. Imagens. Arte.

ABSTRACT DOLLS, ROBOTS, NARCISSUS AND FETISHES: SELFFORGETFULNESS AND THE DEHUMANIZATION OF THE OTHER

Inspired by the Mnemosynes of Warburg, I construct a board in which I put some images of varied categories (films, paintings, artistic performances etc.) to dialogue with images of the Melissa Loverobots advertising campaign. I face debates about a fetishistic and narcissistic subjectivity stimulated by consumer society and I reflect on an ideal of identity associated with the image of the body. Also, I question the narcissistic and fetishistic relationship that we can establish with digital technologies, especially with the so-called robots and social networks. I conclude with the defense of educational processes that question such phenomena and promote alternative experiences.

Keywords: Fetishism. Narcissism. Visual Culture. Images. Art.

RESUMEN MUÑECAS, ROBOTS, NARCISO Y FETICHES: EL OLVIDO DE SÍ MISMO Y LA DESHUMANIZACIÓN DEL OTRO Inspirado en las Mnemosynes de Warburg, construyo una plancha en la cual coloco imágenes de variadas categorías (cinema, pintu- 
ras, performances artísticas etc.) para dialogar con las imágenes de la campaña publicitaría Melissa Loverobots. Enfrento debates sobre una subjetividad fetichista y narcisista estimulada por la sociedad de consumo y hago reflexiones acerca de un ideal de identidad asociado a la imagen del cuerpo. Cuestiono la relación narcisista y fetichista que podemos establecer con tecnologías digitales, en especial, con los llamados robos y redes sociales. Concluyo con la defensa de procesos educacionales que cuestionen tales fenómenos y promuevan experiencias alternativas.

Palabras clave: Fetichismo. Narcisismo. Cultura Visual. Imágenes. Arte.

A cultura visual é um campo interdisciplinar que investiga como se interligam cultura e experiências visuais (MITCHELL, 2002). Por um lado, discute o modo como nossa dimensão cultural influencia como vivenciamos as experiências visuais e como predispõe certas formas de organização da vida social através da consolidação e da regulação dos eventos visuais. Por outro lado, põe em questão o papel destas experiências visuais, enquanto práticas que por sua vez produzem significado e modos de subjetivação.

Em sua vertente educacional, este campo vincula-se à pedagogia crítica, revisada pelo debate pós-moderno. Assim, busca identificar como discursos/saberes materializam-se em experiências visuais para moldar/modular como vivenciamos a nós mesmos, nosso entorno e como interagimos com o mundo; expor verdades naturalizadas inseridas nesses discursos e estimular o desejo de conhecer a sociedade e também de transformá-la. Algumas de suas estratégias são: detectar regularidades e diferenças em meio à profusão de experiências visuais; contextualizar estas manifestações visuais, traçando sua história e questionando como engajam-se nos jogos culturais; confrontar distintas interpretações sobre tais experiências, valorizando vozes antes não autorizadas e incentivar diálogos. É fundamental para este projeto promover o desenvolvimento de narrativas visuais que construam avaliações críticas da sociedade e apontem caminhos alternativos (MARTINS, 2007; AGUIRRE, 2011; HERNANDEZ, 2011).

Como professor pautado pela educação da cultura visual, sigo atento a possiveis discussões da inter-relação entre cultura e experiências visuais. Neste sentido, mantenho um diário com reflexões sobre prováveis frentes de pesquisa. Algumas estendem-se por meses, outras por anos. Neste artigo registro uma investigação que desenvolvo há no mínimo cinco anos e teve início a partir do choque com uma única imagem publicitária.

Muitas campanhas publicitárias impactamme, produzindo o efeito de um poderoso enigma. Este foi o caso do desconcertante anúncio "loverobots" (2006), da marca Melissa de calçados plásticos femininos. Logo descobri outros dois anúncios igualmente intrigantes da campanha. Várias questões marcaram-me de imediato: por que mulheres são representadas como bonecas? Por que robôs amantes? Como essas imagens podem auxiliar a pensar a sociedade em que vivemos? Surgiriam em outro momento histórico? 0 que elas revelam sobre nosso tempo? Que sentidos e significados reforçam? De que modo se engajam nos jogos culturais que produzem a nós mesmos e a esta sociedade?

Para construir uma narrativa que me auxiliasse a enfrentar não simplesmente esta 
campanha, mas aspectos da história da cultura em que surge, ao longo dos últimos anos, venho "catando" outras imagens. A escolha das imagens oscilou da consciência de seu valor a uma vaga intuição. Aos poucos fui construindo com o auxílio do site Prezi uma prancha na qual organizo diálogos entre estas imagens. Percebi, gradativamente, que estes diálogos me levavam a certos focos de análise: narcisismo e fetichismo. Neste artigo, construo essas narrativas e minhas reflexões sobre elas.

Figuras 1, 2 e 3 - Anúncios Melissa Loverobots.
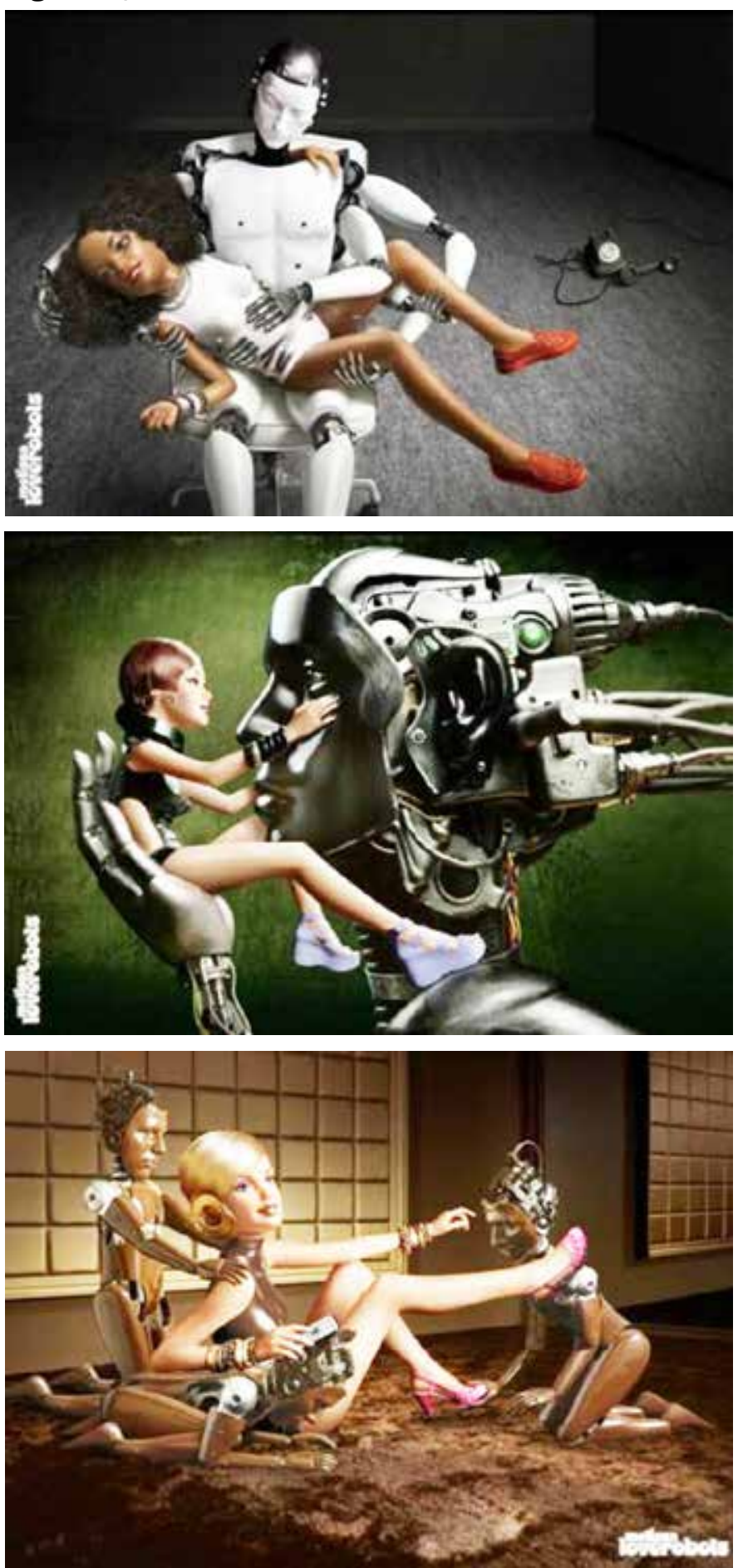

Fonte: Disponivel em: <http://www.mirofotografo.com.br/

post.php?id_post=37\&cat=\&subcat=3>. Acesso em: $07 \mathrm{fev} .2017$. 
Figura 4 - Prancha

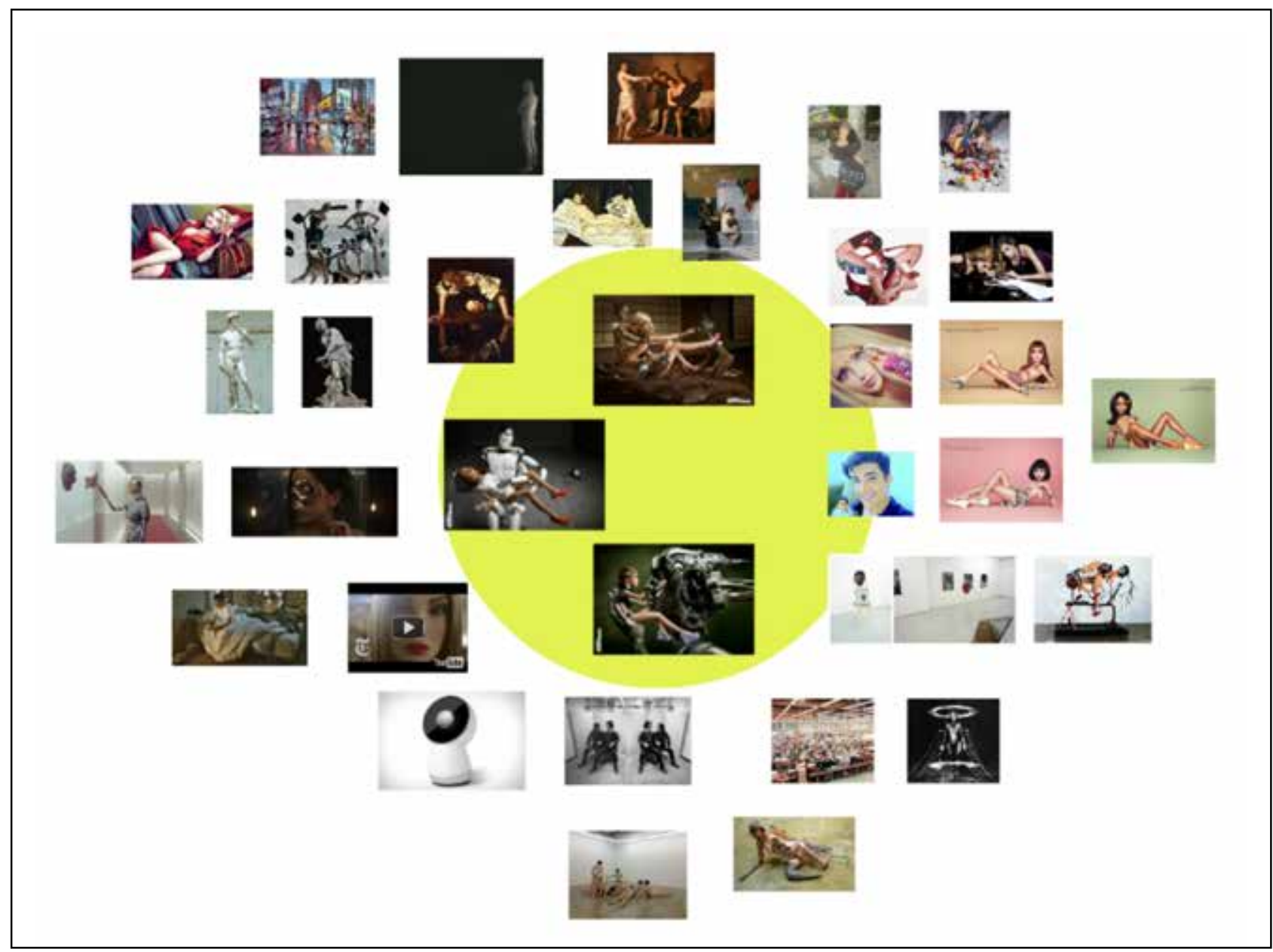

No primeiro tópico, debato sobre uma subjetividade fetichista e narcisista, estimulada pela sociedade de consumo, destacando a importância da imagem do corpo para este sujeito; no segundo, discorro sobre a relação narcisista e fetichista que podemos estabelecer com tecnologias sociais, em especial, com robôs e redes sociais.

Antes de prosseguir, preciso assumir aqui minha inspiração nas Mnemosyne de Aby Warburg, quadros com os quais o historiador "pretendia firmar sua procura de entendimento das culturas humanas", relacionando imagens de todo tipo para que "pudessem entrar em diálogo, se pensar entre si" (SAMAIN, 2011, p. 36). Em minha prancha, como o próprio Warburg, aproximo diversas modalidades de imagens. Relaciono, sem pudores, as peças da campanha Loverobots a imagens de performances, esculturas, pinturas, curtas e longas cinematográficos e publicidades que considerei produtivas. Ressalto, ainda, que, como Warburg, penso que as imagens são “'atos', memórias, questionamentos" e, ainda, "visões e prefigurações" (SAMAIN, 2011, p. 40). Por meio delas, podemos provocar reflexões sobre passado, presente e futuro. Por isso, não só me remeto a histórias de um passado, mas levanto críticas sobre fenômenos ainda emergentes, como o mercado dos robôs sociais amantes.

\section{Sociedade de consumo,}

\section{narcisismo e fetichismo}

\section{Publicidade, propaganda, projeção e identificação}

Ao invés de descrever ao modo iconográfico 
ou formalista elementos ou aspectos de uma imagem, quero propor uma avaliação sobre afetos entre observador e imagem. Ocorre que o sucesso da grande maioria das campanhas publicitárias ou propagandísticas depende da capacidade de suscitar um vínculo emocional com o expectador. Tal relação, portanto, não se explica como um momento objetivo ou racional em que um indivíduo decodifica uma mensagem e avalia seu argumento (PORTUGAL, 2011).

Muitas destas campanhas agem como um convite à fantasia. Uma possibilidade de devaneio estabelece-se por meio da identificação e projeção de si na personagem central da narrativa (CAMPBELL, 2001). Loverobots é uma destas campanhas. Aqui o(a) consumidor(a) que olha a imagem da personagem representada, pode identificar-se com ela, projetar-se nela, ver a si como boneca e objeto do olhar desejoso do outro (neste caso, representado pelo robô). Um modelo para este processo é a projeção narcisista, a paixão por uma imagem, que se sente como a manifestação do eu ideal. Como diz Machado (2007, p. 52-53), “identificando-se com as personagens, o espectador converte a tela transparente em espelho, onde ele vê projetado o(s) seu(s) ego(s) ideal(is) e onde ele pode fazer um reconhecimento feliz". Embora seja ele(a) mesmo(a) quem vê a imagem, pode, apesar disso, nas fantasias e devaneios de sua mente, imaginar-se sendo visto(a) e deleitar-se com o prazer de ver-se (como em um espelho) e se ver sendo visto(a) (MULVEY, 2011).

Algumas campanhas deixam explícito este prazer de ver-se sendo visto, representando protagonistas sendo seguidos por olhares desejosos ou de admiração. Muitas propõem esse devaneio narcisista de modo menos evidente, no geral, por meio da identificação com imagens de celebridades.
Figura 5 - Campanha de Dolce \& Gabbana.

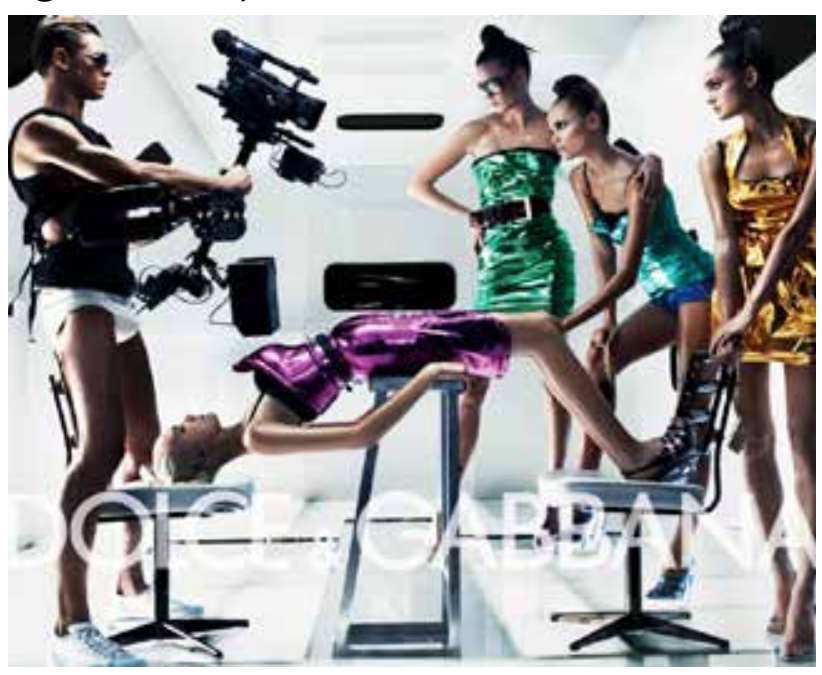

Fonte: Disponivel em: $<$ http://www.glamourboysinc. com/2011_11_27_archive.html>. Acesso em: 07 fev. 2017.

Será possivel construir uma história cultural de tal relação com imagens? Apenas em certos sentidos, a arte barroca é o paradigma da estratégia de projeção para a persuasão da publicidade comercial de hoje. Como afirma Argan (2004), o barroco foi uma arte de persuasão. Teve como objetivo persuadir e determinar modos de comportamento. Por isso, focou nas disposições sentimentais, não do artista, mas do público a que se dirige. Com o conhecimento sobre as disposições deste público, quis fazê-lo sentir dor, enjoo, arrepio, compaixão. Para tanto, e isto foi fundamental, o divino foi apresentado com corpo e expressão mundana (não idealizadas), seres com os quais, esperava-se, os indivíduos pudessem se identificar.

A identificação como meio de persuasão foi tanto estratégia da propaganda católica quanto é da publicidade comercial. Contudo, alguns aspectos distanciam o tipo de identificação de viés narcisista, o proposto por campanhas como Loverobots, e a identificação esperada por artistas barrocos. As imagens barrocas propunham empatia com o que antes fora descrito como demasiadamente distante da vida comum. A identificação com os sentimentos de personagens bíblicas, com seus êxtases e 
dores, teve como intensão fortalecer nas pessoas a crença de que elas podem e devem inspirar suas ações nas histórias sagradas, já que seriam histórias de pessoas reais. As imagens deveriam engajar os espectadores em certos princípios morais e influenciar comportamentos, daí sua função pedagógica.

$\mathrm{Na}$ obra Narciso (1597) de Caravaggio, um dos grandes artistas apropriados pela Contrarreforma na consolidação das imagens para a catequização, podemos encontrar um alerta para o risco da projeção narcísica - risco não previsto pela tradicional iconoclastia atormentada por demais, como descreve Wolff (2005), com o desvio dos idólatras. Como alguém pode dar a devida atenção aos desígnios de Deus se está embriagado no que fantasia ser seu reflexo ideal? Uma experiência é sentir-se empático a uma pessoa representada de maneira comum, de tal forma a projetar-se em suas histórias e aprender com elas; outra experiência diferente é fantasiar ser alguém idealizado e apaixonar-se por este reflexo.

Figura 6 - Caravaggio - Narciso (1597).

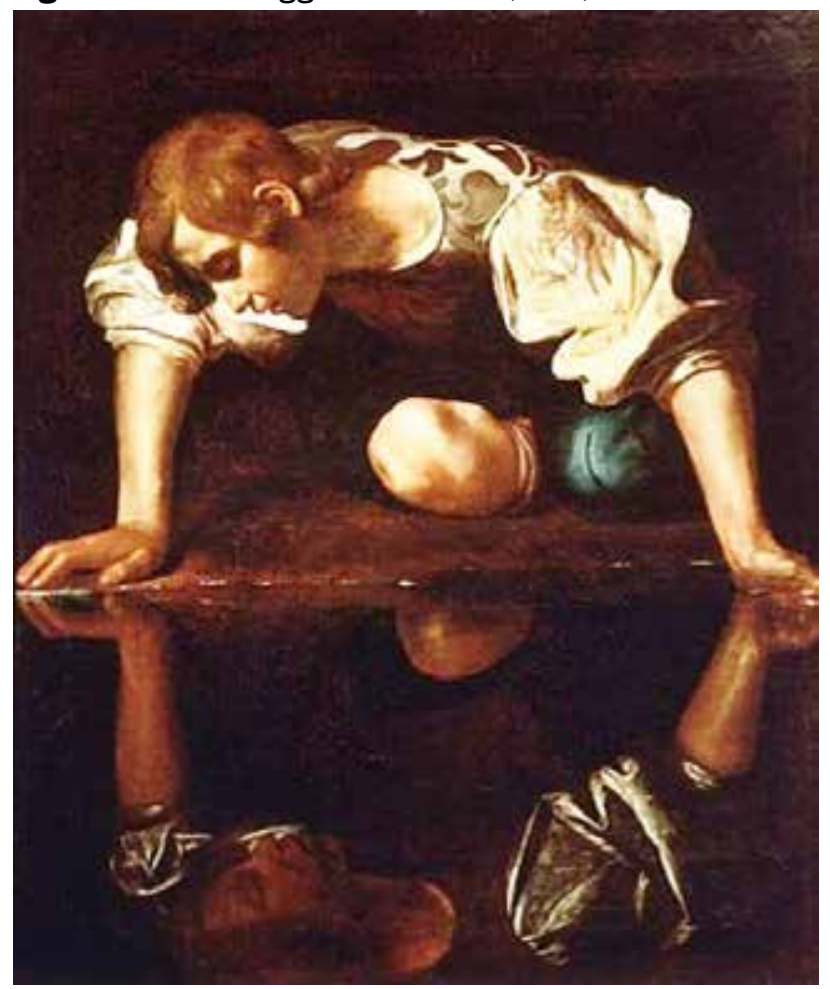

Fonte: Disponivel em: <http://www.arte.it/opera/narciso-98>. Acesso em: 07 fev. 2017.
Ao contrário da propaganda católica, publicidades como a de Melissa pertencem a uma sociedade pautada e interessada em subjetividades específicas. 0 barroco pressupunha um observador próprio ao seu tempo. É preciso compreender mudanças que determinam características específicas do sujeito contemporâneo, pois a projeção narcisista ganhará maior espaço numa sociedade individualista, marcada por uma cultura da vaidade, uma sociedade de consumo e hedonista.

\section{Individualismo, cultura da vaidade e narcisismo}

Para avançar, o pontapé inicial precisa ser o lugar do indivíduo e mesmo da noção de indivíduo em nossa sociedade. Tomamos tal noção como tão natural e fundamental que pode parecer-nos contraintuitivo questioná-la. Para Elias (1994, p. 129), é “necessário um considerável esforço de desprendimento dos pressupostos que se tenha", para darmo-nos conta de que houve um momento em que a noção de indivíduo que utilizamos hoje pareceria inconcebível. Elias argumenta que especialmente na pré-história, a dependência do ser humano à vida comunitária era tanta que incidia no modo como imaginava a si: menos como autônomo e mais como parte de um todo. Assim, a compreensão atual da função da noção de indivíduo, "expressar a ideia de que todo ser humano do mundo é ou deve ser uma entidade autônoma e, ao mesmo tempo, de que cada ser humano é, em certos aspectos, diferente de todos os demais, e talvez deva sê-lo" (1994, p. 130), expressa uma transformação histórica que alterou o privilégio desta identidade-nós para uma identidade-eu.

Este autor descreve o Renascimento como o momento crucial desta inversão, em razão de que foi quando "mais e mais frequentes se tornaram os casos de pessoas cuja identidade-nós enfraqueceu a ponto de elas se afigu- 
rarem a si mesmas como eus desprovidos de nós". Não se tratou obviamente do fim absoluto da "identidade-nós", mas é de se ressaltar que a partir de então esta passou a "ser obscurecida ou ocultada, em sua consciência, pela identidade-eu (1994, p. 161). Elias (1994, p. 163) ressalta como uma das evidências deste processo a ascensão desde então de relatos literários do "problema da pessoa que se percebe como totalmente só e não consegue resistir à dúvida sobre a existência de qualquer coisa ou qualquer pessoa fora dela mesma", cujo exemplo paradigmático foi o cogito cartesiano.
Há uma solidão subjacente em Melissa Loverobots, apesar dos personagens aparentemente não estarem sozinhos, desde que o uso dos robôs remete às tecnologias de comunicação às quais milhares de sujeitos contemporâneos apelam em busca da sensação de conexão. Também o aspecto soturno e claustrofóbico do espaço retratado traz esta sensação. Este aspecto me lembra alguns desenhos de Gil Vicente, apesar de que nestas obras o sujeito não apela a nenhuma estratégia de distanciamento de si. $\mathrm{Nu}$, consciente de sua solidão, confronta-se só consigo e suas dores.

Figura 7 - Desenhos de Gil Vicente.
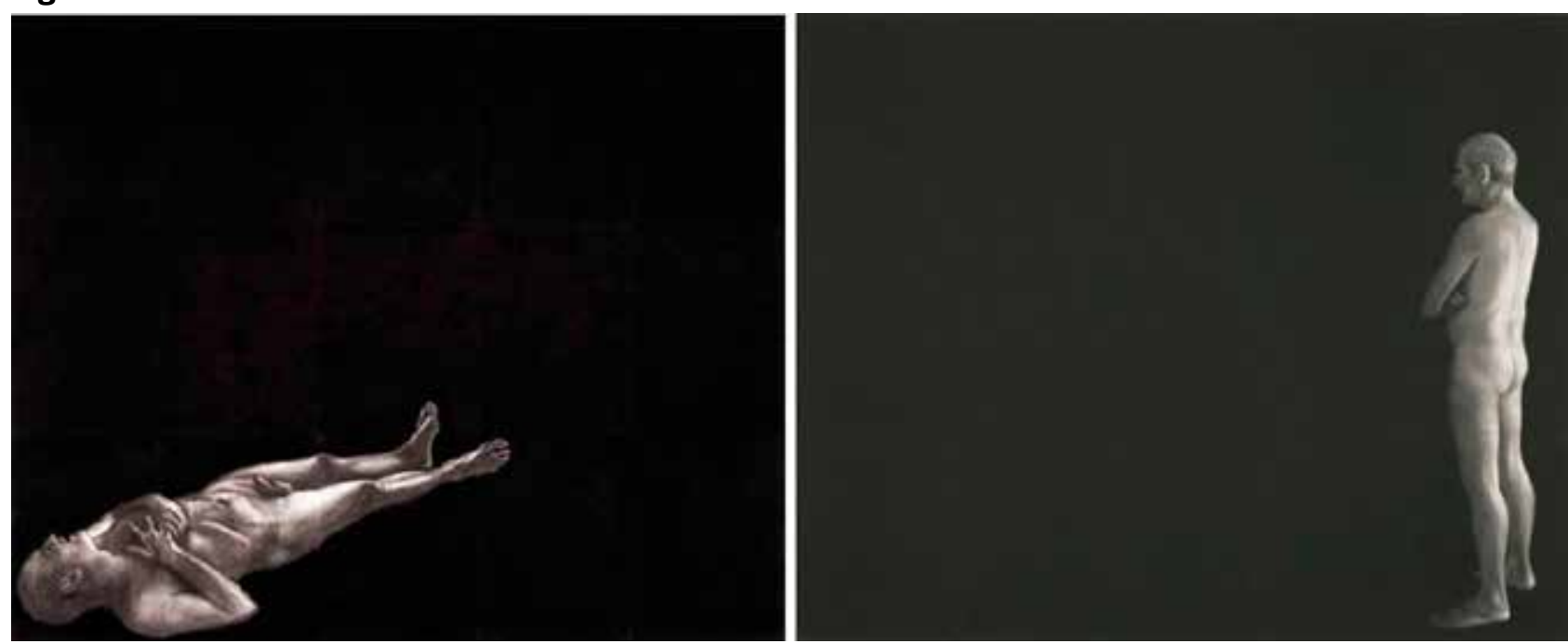

Fonte: Disponivel em: <http://www.onordeste.com/portal/gil-vicente/>. Acesso em: 07 fev. 2017.

Mesquita (2004) observa que só é possível pensar o atual fenômeno da moda com a devida atenção a sua relação com a "era do individualismo". Ela ressalta o desenvolvimento de uma relação intrassubjetiva específica a esta era. Por mais estranho que pareça, "o fato é que nem sempre o sujeito 'se pensou', como hoje o faz, em função de que "as explicações para os acontecimentos e experiências humanas já se localizaram predominantemente 'fora'” (2004, p. 24-25). Campbell (2001) dá um dado que ajuda a compreender a afirmação de Mesquita. Segundo este autor, "na Idade Média, palavras como 'medo' e 'alegre' não denotavam sentimento localizado dentro de uma pessoa, mas atributos de acontecimentos externos, referindo-se 'medo' a um acontecimento repentino e inesperado, e feliz a uma peculiaridade de coisas como o dia ou a ocasião" (2001, p. 106-107). Foi com os tempos modernos que as emoções foram entendidas como propriedades dos indivíduos e não como propriedades de eventos externos. A prática da autoavaliação, a busca da consciência de si e da autoexpressão, serão possibilidades a partir deste processo, na medida em que os indivíduos agora podem encontrar em si próprios as razões de suas emoções.

Mais à frente volto a esta questão, pois a subjetivação das emoções e a competência 
de controlá-las serão fundamentais para a capacidade do sujeito contemporâneo de manipulá-las, promovendo por meio de fantasias/ devaneios os prazeres fetichistas/narcisistas. No momento, interessa destacar este ponto como parte de um processo amplo de individuação. A este processo que faz depender da autoanálise a compreensão da identidade e das emoções, aponto ainda discursos, poderes e técnicas que implicar-se-ão na subjetividade contemporânea e serão determinantes como estímulos à projeção narcisista: o enfraquecimento dos "espaços de ação intersubjetiva" e a amplificação do valor do "autoinvestimento".

Aspectos da modernidade como fragmen- tação e efemeridade dos laços sociais levam a “maior impermanência das relações-nós, que nos estágios anteriores tinha muitas vezes o caráter vitalício e inevitável", o que amplifica a "ênfase no eu, na própria pessoa, como o único fator permanente, a única pessoa com quem tem que se viver a vida inteira" (ELIAS, 1994, p. 167). Na obra Nyc6am, de Nathan Walsh, identifico esta solidão na multidão, sentimento marcante na vida urbana. Por meio da proporção dos telões, que apequenam os indivíduos, o quadro também aponta para a importância da mídia em nossa sociedade, de imagens como os anúncios de Melissa Loverobots.

Figura 8 - Nyc6am de Nathan Walsh.

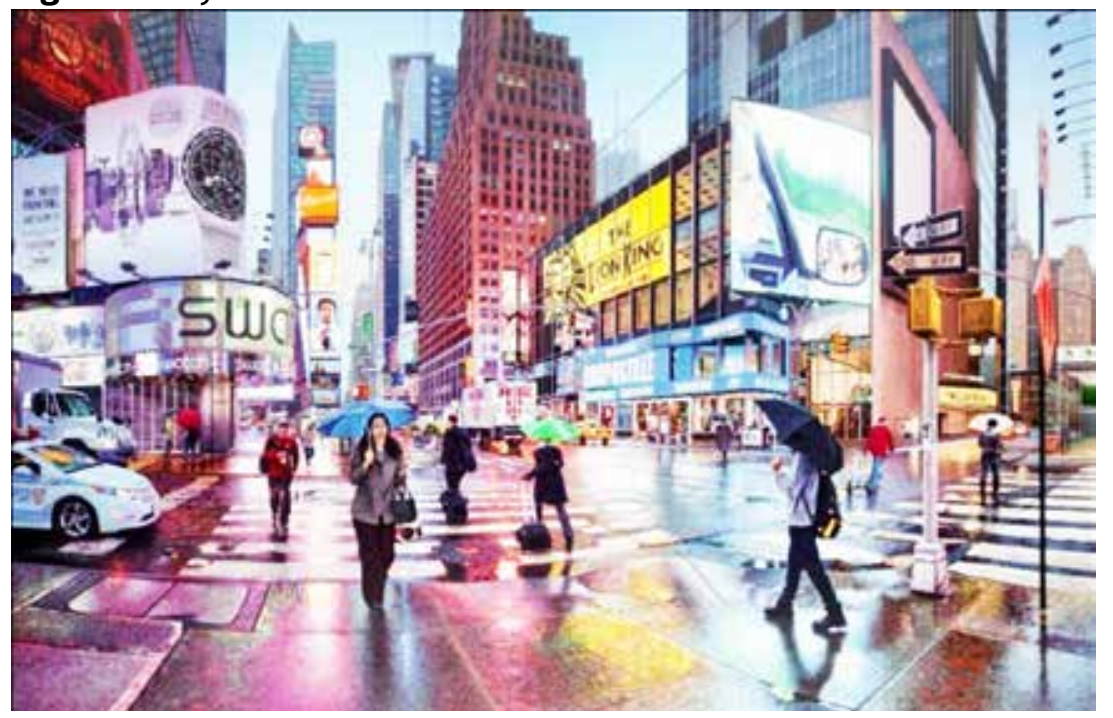

Fonte: Disponível em: <http://www.nathanwalsh.net>. Acesso em: 07 fev. 2017.

Acompanha a fragmentação social o discurso liberal que justificou o individualismo pela crença de que cada um deve ter como foco de suas energias lutar por benefícios próprios. No contexto ideológico em que surge o liberalismo, ainda havia, todavia, uma preocupação com a concepção de uma igualdade formal entre os homens (LAGASNERIE, 2013). Com o neoliberalismo, isso muda. Agora, os mecanismos concorrenciais e a desigualdade que promovem devem pautar as nossas relações, criando um ambiente que amplifica o processo histórico de interiorização da subjetividade ao minar "princípios comunitários, coletivos, sociais" (MANCEBO, 2002, p. 100).

Somados, o rebaixamento dos compromissos comunitários e o valor da competição e a naturalização da desigualdade acabam por potencializar na era do individualismo neoliberal isto que La Taille (2009) chama de cultura da vaidade. Segundo este autor, a sociedade atual sobrevaloriza o "vencedor". Quem é este? Em primeiro lugar, "o vencedor não é apenas quem se dá bem na vida, mas quem se dá melhor que os outros" (2009, p. 172). Como baseia-se na vaidade, exige, portanto, o estabelecimento de 
superioridade. Não bastaria uma relação de reconhecimento recíproco, alguém deve estar por baixo. Nem tão pouco pode funcionar com 0 simples autojuizo positivo. Há o desejo do olhar do seu outro, o perdedor. Em uma cultura da vaidade, presume-se a necessidade da admiração alheia, como se fosse o fim em si de nossas ações. Assim, a sensação de invisibilidade torna-se um martírio. Mais que respeito, o sujeito quer admiração, para tanto, procura se destacar e impressionar. $O$ vencedor será aquele que tem "marcas que o tornam visivel aos olhos de todos". Por fim, o que se observa agora é valor oposto ao da época em que a identidade-nós reinava sobre a identidade-eu: agora, sentir-se igual a todos pode ser motivo de vergonha e perceber-se diferente, razão de orgulho.

Proponho que há relação entre a era do individualismo pautada por uma cultura da vaidade e uma subjetidade narcisista. Yontef (1998, p. 308-309) ressalta que se o narcisista é autocentrado, é adequado percebê-lo não em si mesmo, mas na imagem idealizada de si. Por isso, ele não é autossuficiente, carece do olhar de admiração dos outros. No fundo, "as pessoas narcisistas sentem muita vergonha e usam algo externo para thes suprir um sentimento de segurança, coesão e autocarinho" (1998, p. 315). Quando o meio não corresponde de modo a confirmar sua autoimagem idealizada, alimentando seu exibicionismo, confirmando sua sensação de grandiosidade e submetendo-se a sua expectativa de receber favores especiais, o narcisista entra em uma crise que pode se manifestar inicialmente na raiva contra o outro. Em última instância, "quando não são reconhecidos, quando seus sentimentos e necessidades não lhes são espelhadas de volta, sentem-se invisiveis e sua existência psicológica, assim como seu bem-estar, estão ameaçados" (1998, p. 315)

Em virtude de tamanho impacto, sentem que precisam proteger a todo custo a fantasia da autoimagem idealizada. Sua relação consigo mesmo e com os outros se torna superficial. Vivem duplamente alienados. "Eles estão alienados de outras pessoas porque são autocentrados, e estão alienados de seu(s) self(ies) verdadeiro(s) porque estão centrados em sua autoimagem e não em quem verdadeiramente são e o que de fato experienciam" (1998, p. 313). Logo, a solução de suas angústias passa por desenvolverem a capacidade de "se aceitar, nutrir e respeitar como são", passa por aprenderem a "ficar em contato com sua maneira real de ser" e também por "fazer contato verdadeiro" com os outros a sua volta (1998, p. 315).

Podemos concluir que, com o enfraquecimento das referências grupais que consolidavam uma identidade-nós, eleva-se o indivíduo, o valor da identidade-eu. 0 indivíduo passa a viver a responsabilidade de solucionar a pergunta "quem sou eu?" com uma resposta adequada ao valor moderno de autonomia. Contudo, sob a interferência dos valores da cultura da vaidade, do individualismo neoliberal, pode seguir uma resposta narcisista: a importância subjetiva de identificar-se com uma autoimagem de vencedor, destacada, especial, visível aos olhos de todos, que exige a superioridade em relação ao outro e o olhar de admiração deste outro.

\section{Fetichismo, sociedade de consumo e cultura hedonista}

Nossa "sociedade do consumo" insufla tal vaidade e narcisismo. É evidente que hoje engajamo-nos em rituais de consumo, em grande parte, por serem formas de possuir e exibir marcas visuais que nos diferenciem, que expressem nossa identidade-eu, e que nos descrevam em algum sentido como vencedores. Para compreender como práticas de consumo e narcisismo potencializam-se mutuamente, cabe avaliarmos uma lógica fetichista de consumo. 
Tanto Marx quanto Freud utilizaram a palavra fetiche para descrever o ocultamento de algo (KEHL, 2004a). Em Marx, a mercadoria funciona como fetiche, no sentido de que seu culto oculta as condições materiais de sua produção. Em Freud, o fetiche é algo com o qual o indivíduo livra-se do pavor da castração (ZANA; PERELSON, 2012). De acordo com o pai da psicanálise, para o fetichista, o objeto fetiche teria assim grande importância em sua vida sexual e na psique de modo geral. A obra Caradisiac $n^{\circ} 7$ (2007), de Till Rabus, ajuda-me a pensar sobre esta lógica. Nela, o artista faz estranhar a erotização fetichista proposta com frequência por publicidades de veículos quando a posse do carro associa-se à posse do corpo feminino.

Figura 9 - Caradisiac $n^{\circ} 7$ (2007).

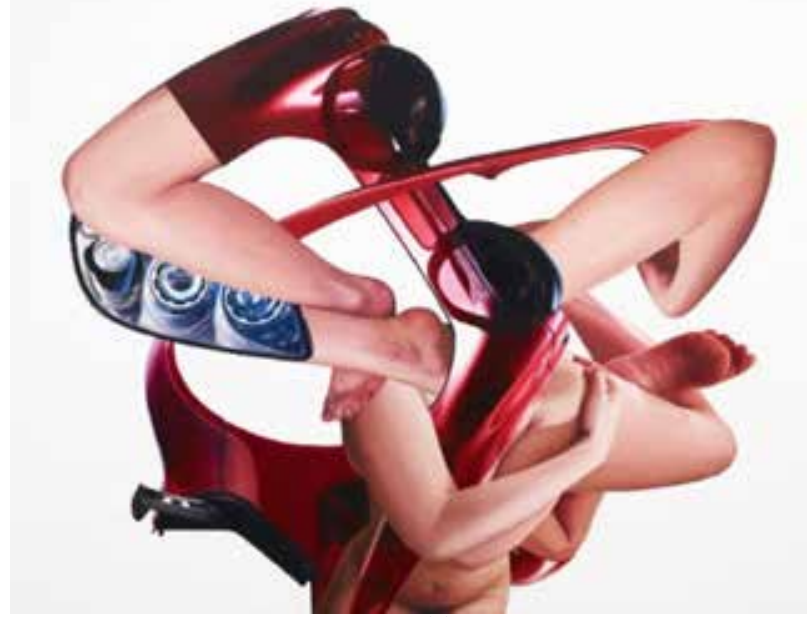

Fonte: Disponivel em: <http://www.tillrabus.ch>. Acesso em: 07 fev. 2017.

Kehl (2004a) destaca a interpretação de Lacan sobre o fetichismo. Esta avaliação ressalta que conviveríamos com um sentimento de falta, carência, desde que nos reconhecemos como entidades separadas, como sujeitos separados uns dos outros. 0 desejo estrutura-se a partir desta falta, segundo Lacan. Para Kehl, a publicidade apelaria à descrição de nosso presente como carente, estimulando o desejo por um estado de resolução futuro através do consumo.

A oferta de mercadorias e a onipresença das solicitações da publicidade, emitidas a partir desta nova encarnação do Outro representado pela mídia eletrônica, produzem a ilusão de que nada se perdeu e de que temos à nossa disposição uma profusão de objetos para simular o objeto perdido de nosso mais gozar, o tal objeto a. (2004a, p. 75)

Funcionando como uma denegação da falta, o fetichismo é um dos principais efeitos subjetivos da cultura de consumo, desde que esta passa a vender não apenas produtos, mas justamente a ilusão de posse do "objeto $a$ ", que fundamentaria tanto uma concepção de si ideal, uma identidade plena, quanto um estado emocional, o retorno ao estado de "mais-gozar". Aí encontramos as duas dimensões fundamentais do narcisismo, a percepção de si como ideal e o prazer decorrente disso. Não é à toa que narcisismo e narcótico têm a mesma origem etimológica. "Narciso é uma flor cujo nome é derivado da palavra grega narke (de onde tiramos narcótico) devido ao seu poder de aliviar a dor e o sofrimento" (O'DONOHUE, FOWLER; LILIENFELD, 2010, p. 228). Algumas campanhas revelam sem nenhum receio o uso do ritual de consumo como ritual de entorpecimento prazeroso.

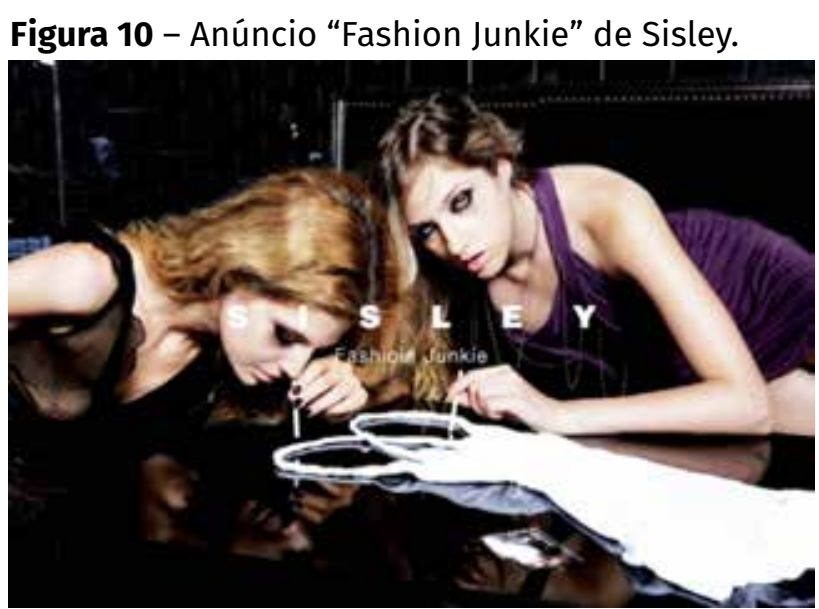

Fonte: Disponivel em: <https://visualities2012.wordpress. com/2012/11/27/image-5/> Acesso em: 07 fev. 2017.

Tal promessa de "mais-gozar", é evidente, tem muito pouco a ver com os imperativos de renúncia e recalque que outrora foram hegemônicos em nossa sociedade. "O imperativo do gozo substituiu a interdição do excesso, e embora gozar plenamente seja impossivel 
para o ser humano, é este gozo que o super-eu, reproduzindo o discurso dominante e os valores em circulação exige dos sujeitos" (KEHL, 2004a, p. 74). Na conversão de uma sociedade de produção, para uma sociedade de consumo, um hedonismo específico ganha evidência e valor social. Trata-se de um hedonismo possibilitado pelo processo de interiorização ou subjetivação das emoções, assim como descrito acima. Como diz Campbell (2001, p. 115), “o hedonista contemporâneo é um artista do sonho, que as especiais habilidades psíquicas do homem moderno tornaram possíveis". Aqui, a estimulação de sensações de prazer tem como principal motor não os estímulos externos por si, mas a capacidade do indivíduo de devanear e fantasiar. "Criam-se fantasias convincentes, de tal modo que os indivíduos reagem subjetivamente a estas como se fossem reais. esta uma propriedade nitidamente moderna, a aptidão de criar uma ilusão que se sabe falsa, mas se sente verdadeira" (CAMPBELL, 2001, p. 115). Assim, há um esforço subjetivo por engajar-se nas fantasias criadas por publicitários e melhor experimentar objetos como fetiches. Muitas publicidades até representam esta relação entre consumo e devaneio. Por exemplo, uma da cervejaria Devassa em que ao ver uma cerveja transbordar um homem se imagina encharcando uma modelo com uma mangueira ou uma outra de HB20 em que ao tocar no carro um homem fantasia flutuar ao redor de uma estação espacial.

Busca-se, pelo consumo, preencher uma carência do ego, dar uma coerência, fortalecer uma narrativa de eu. 0 produto é um instrumento mágico de denegação da falta, logo, de afirmação de uma imagem de si plena. “É a nossa pulsão para preencher esta falta que possibilita à publicidade endereçar-se aos nossos desejos de modo tão cativante. A publicidade frequentemente recria para nós a fantasia de ego-ideal perfeito, facilitando a regressão a esta fase infantil" (STURKEN; CARTWRIGHT, 2001, p. 217).

\section{Que ideal de plenitude? A imagem do corpo}

Afirmamos acima que o fetiche é objeto no qual nos ancoramos para ocultar uma sensação de vazio. Por meio dessa ocultação, buscamos a fantasia da identidade plena e por meio dela o regozijo. Contudo, uma nova questão se coloca: como se apresenta o ideal de identidade em nossa cultura? Sabemos que este eu-ideal só pode ser imaginado através do que supomos ver no olhar do outro. O outro, na psicanálise, é inicialmente representado pela mãe. Contudo, pode-se dizer que a sociedade toma este papel e que na sociedade contemporânea as mídias se tornaram a arena pública primordial (KELLNER, 2001), o grande outro (KEHL, 2004a). Daí porque é nela que em grande medida visualizamos ideais de identidade. Quais, então, são as qualidades deste eu-ideal apresentado nas mídias? Para Kehl, "só a imagem do corpo próprio - tornado o mais parecido possivel com um corpo Outro, sem história, sem sofrimento e sem falhas - pode servir de suporte para a construção de uma ilusão de identidade para os sujeitos da sociedade do espetáculo (KEHL, 2004b, p. 158-159).

Este eu-ideal, uma imagem, uma imagem do corpo, reflete assim a lógica da sociedade do espetáculo. Para Mesquita, uma "sociedade pautada na valorização da imagem, naturalmente, privilegia discursos por meio da aparência" (2004, p. 67). o corpo, entendido como linguagem, passa a ser compreendido como "o lugar onde a subjetividade é concretamente materializada", daí entendemos "os extremos da ânsia por torná-lo via de 'expressão do eu'", por meio de interferências como o uso de roupas ou de modificações mais intensas com o apelo a remédios, cosméticos, academias ou mesmo à mesa de cirurgia (2004, p. 60-61). 
A importância da imagem do corpo na contemporaneidade fica explícita quando Mesquita $(2004$, p. 67) ressalta que "a subjetividade é bastante assimilada ao corpo como um todo e não ao psiquismo ou à mente". Como indício deste fenômeno, ela destaca que "a partir das mudanças de sua aparência física, [o sujeito contemporâneo] acredita poder fazer operar a garantia de alterações no modo de existência em relação a si" $(2004$, p. 69), ou seja, mudar de visual equivaleria, ou seria condição para mudar de personalidade, desenvolvê-la.

Para Mesquita (2004), os cuidados com o corpo representam quase uma obrigação contemporânea. Em uma cultura da vaidade, ser "feio" é menos uma fatalidade, obra do destino à qual só podemos nos resignar, do que um fracasso pessoal, uma das formas de aparentar ser um perdedor. Assim, em sua manifestação extrema, visualizamos indivíduos autodenominaremse Barbie e Ken humanos. Aqui encontramos a busca por um eu-ideal que existe antes de tudo como imagem, imagem do corpo esculpido pelo Photoshop e que mais lembra cera e plástico do que pele, de corpo construído na academia, na mesa de cirurgia plástica e no consumo.

Figura 11 - Valeria Lukyanova, a Barbie humana.

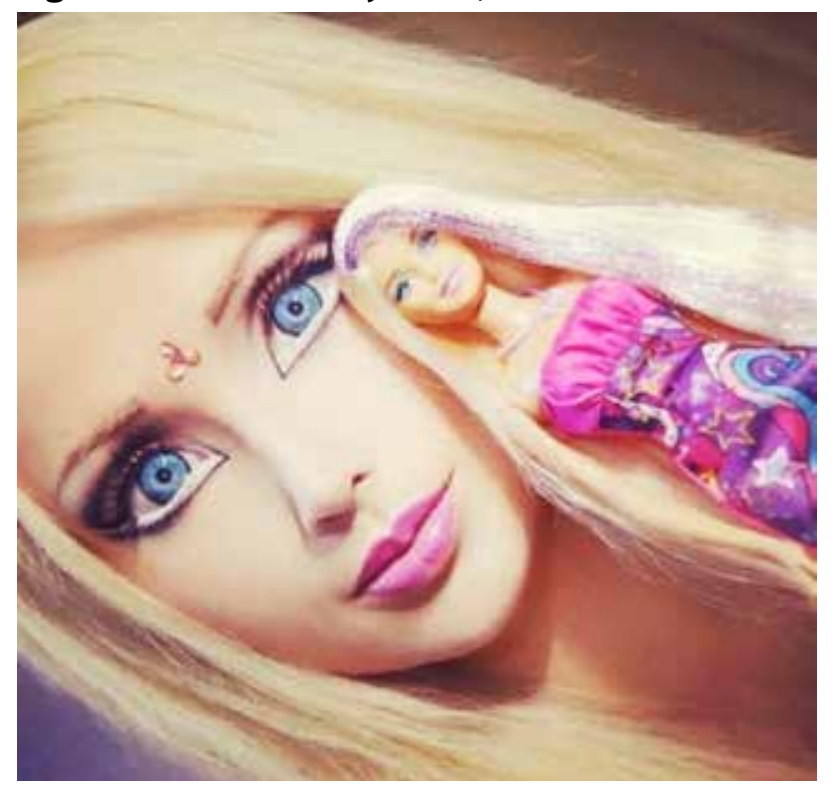

Fonte: Disponivel em: <http://www.glamour.ru/lifestyle/ society/1244896/>. Acesso em: 07 fev. 2017.

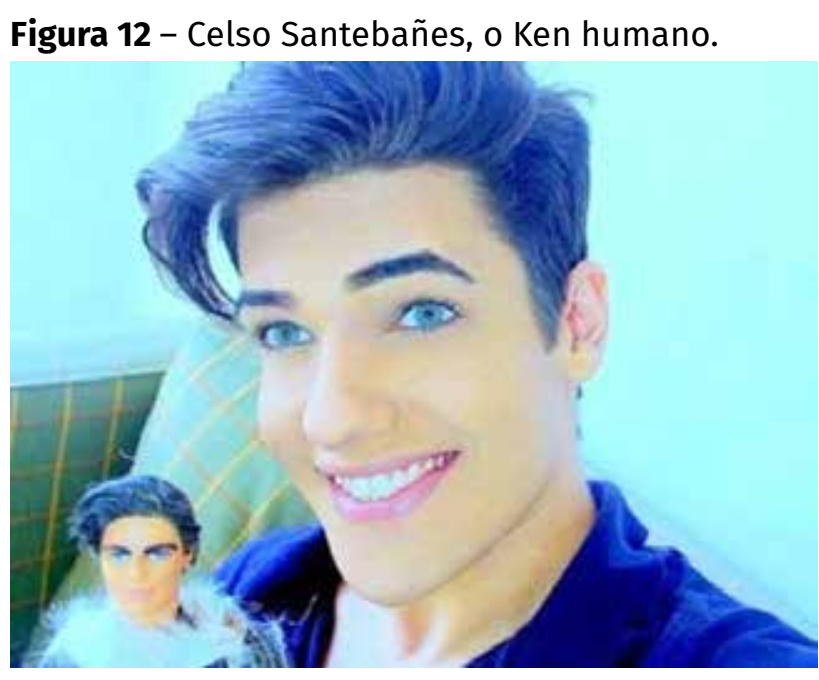

Fonte: Disponivel em: <http://brasil.estadao.com.br/noticias/geral,ken-humano-morre-vitima-de-pneumonia -em-mg,1700429>. Acesso em: 07 fev. 2017.

É a este ideal de plenitude, expresso em um corpo "perfeito", que nos remete ao corpo com rosto de boneca e sandálias Melissa. Tradicionalmente, os comerciais de Melissa criam a associação entre o plástico, material das sandálias, e o plástico material utilizado para produzir bonecas como Barbie, uma boneca que permeia o imaginário de meninas e mulheres já por muitas décadas. Melissa Loverobots é um excelente exemplo desta identidade construída a partir da imagem de um corpo sem história, preso no presente, sem sofrimento e sem falhas, ao representar o eu ideal não como uma pessoa, mas como uma boneca.

\section{A “desumanização" de si e do outro}

É nesse universo de subjetividades narcisistas, individualistas, fetichistas, consumistas e hedonistas que transita a obra da performer Narcissister. Com seu corpo escultural, a performer encarna o sujeito narcisista contemporâneo utilizando a mesma máscara plástica, o rosto fabricado de boneca, que observamos em melissa Loverobots.

Na obra "You are Narcissister", ela convida espectadores a vestirem a máscara e contemplarem seu reflexo "ideal", por meio de um es- 
pelho. Ao fundo, nas paredes da sala, fotos com o mesmo formato do espelho exibem a "variedade homogênea", fabricada, dos sujeitos na nossa sociedade de consumo. Com a obra "self gratifier", o debate torna-se mais complexo, pois Narcissister performa a relação do nar- cisista com um outro. Como descrevi acima, o narcisista está duplamente alienado, de si e também do outro. Nesta obra, o outro existe apenas enquanto uma máquina não autônoma que está sob o jugo do desejo do narcisista e cuja função é sua gratificação, seu gozo.

Figuras 13 e 14 - Instalação "You are Narcissister" e performance "Self gratifier" de Narcissister.

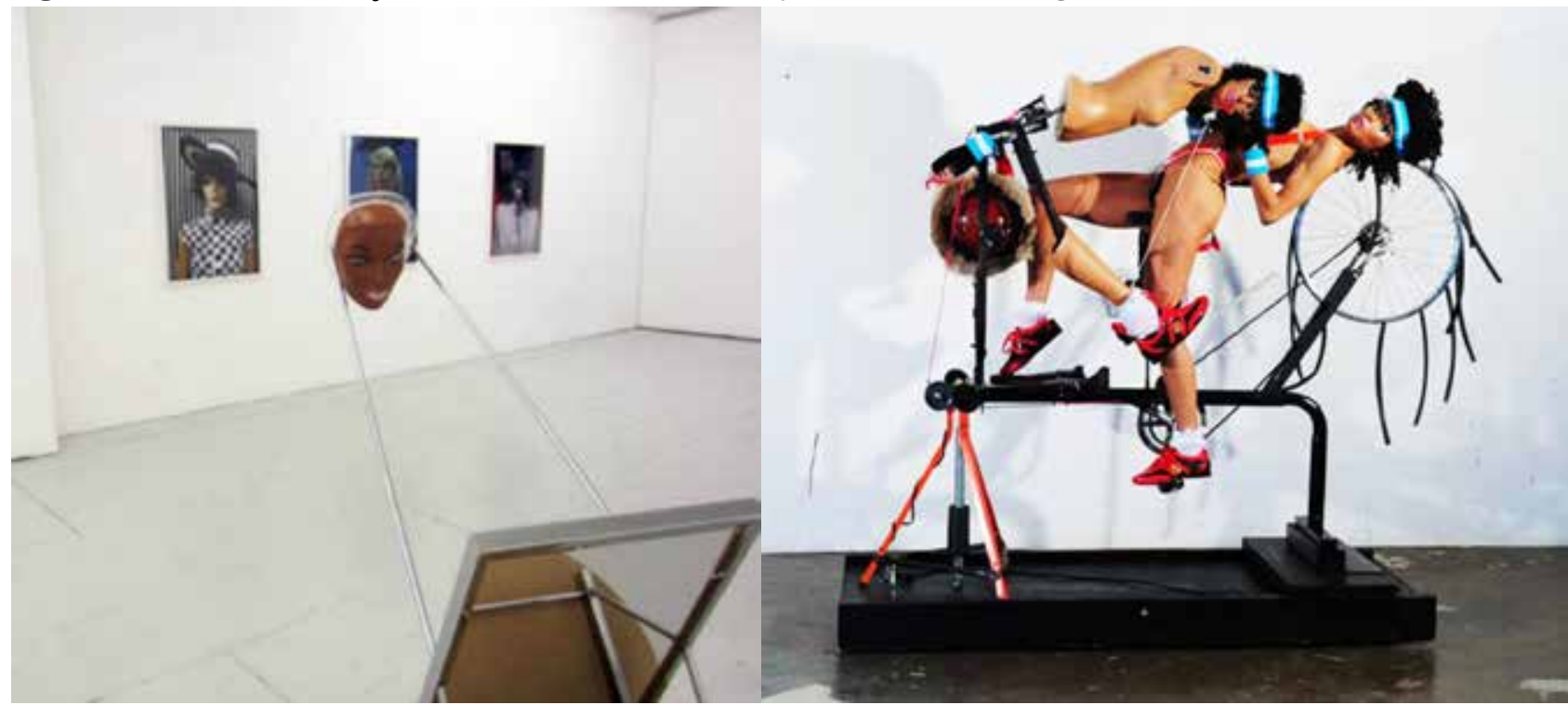

Fonte: Disponivel em: <http://performatus.net/perfil-de-artista/narcissister/>. Acesso em: 07 fev. 2017.

A subjetividade na cultura do narcisismo é a impossibilidade de poder admirar o outro em sua diferença radical, já que não consegue se descentrar de si mesma. Referido sempre a seu próprio umbigo e sem poder enxergar um palmo além do próprio nariz, o sujeito da cultura do espetáculo encara o outro apenas como um objeto para seu usufruto. Seria apenas no horizonte macabro de um corpo a ser infinitamente manipulado para o gozo que o outro se apresenta para o sujeito no horizonte da atualidade. (BIRMAN, 2000, p. 25 apud ESTEVAN, 2008, p. 172).

Afirmar que a diferença radical do outro não é reconhecida indica que não há mesmo uma compreensão da separação entre o ego e o que o rodeia, tudo deve existir sob a égide ou controle do eu, o outro não tem objetivos próprios. Talvez por isso, na obra Self gratifier, de Narcissister, o outro pareça uma simulação do próprio narcisista.
Como vimos, o outro é fundamental, no mundo do narcisista, mas precisa estar, de seu ponto de vista, desumanizado (ESTEVAM, 2008). Segundo Zana e Perelson (2012, p. 2), para o narcisista, o "autocentramento se apresenta por meio da exaltação gloriosa do próprio eu e, no campo do sexual, pela predação do corpo do outro". Na crueza, violência, de seu erotismo, Narcissiter deixa evidente tal predação.

Assim Narcissister discute os dois processos de alienação próprios ao narcisismo, tornar-se imagem e fazer dos outros simples meios de autogratificação. Por isso a obra de Narcissister nos ajuda a questionar Melissa Loverobots. Nesta campanha específica, uma vez no mundo de fantasia do anúncio, o(a) espectador(a) identificar-se-á com uma boneca que tem então nos outros/robôs seus capachos, aqueles que a olham com admiração e 
reverência, que alimentam sua vaidade. Neste anúncio, a alienação pode ser identificada tanto no outro representado como um escravo robô, como neste ser "perfeito" que mais parece produto industrializado, menos um humano de carne e osso, mais uma imagem que existe por si só. Por tudo, a boneca não é tão diferente do robô humanoide. Ambos são, antes de tudo, imagens do ser humano, imagens fabricadas.

Antes de finalizar este tópico, ressalto que, em Loverobots, não há como ignorar que a desumanização também é efetivada com a evocação da história da escravidão. Esta percepção amplia-se no anúncio 2, o que tem uma personagem branca sendo servida por robôs de cor negra. É possivel identificar uma conexão com o discurso racista que justificava o sistema escravista. Nesse sentido, não posso negar a lembrança das obras Estupro de garota negra (1632), de Christiaen van Couwenbergh, e Banho Mouro (1870), de Jean -Léon Gérôme.

Figura 15 - Estupro de garota negra (1632), de Christiaen van Couwenbergh.

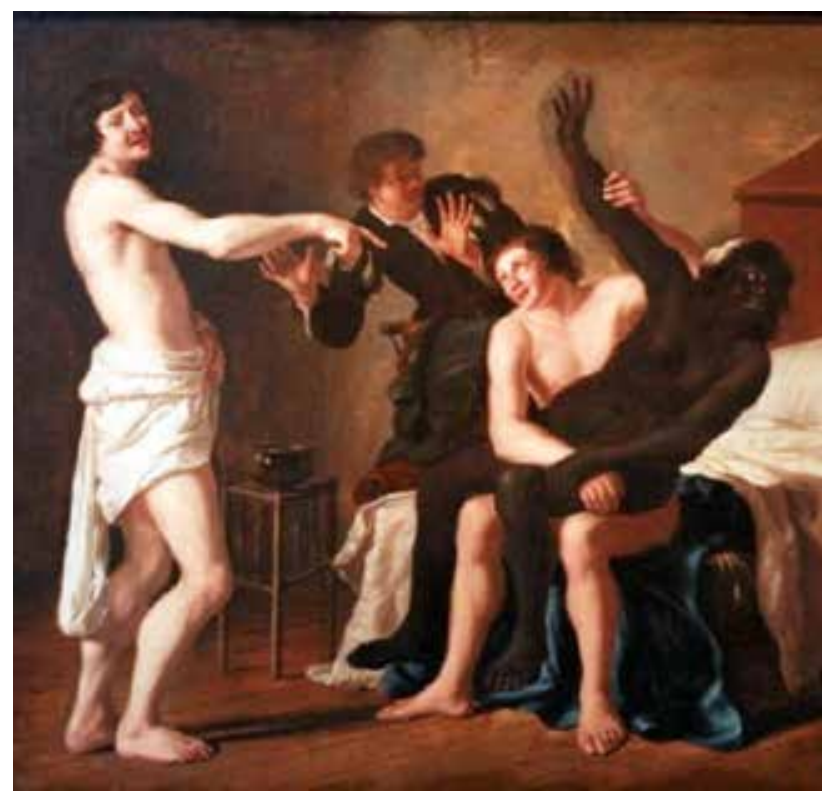

Fonte: Disponivel em: <https://commons. wikimedia.org/wiki/File:Rape of the negro_girlmg_0026.jpg>. Acesso em: 07 fev. 2017.
Figura 16 - Banho Mouro (1870), de Jean-Léon Gérôme.

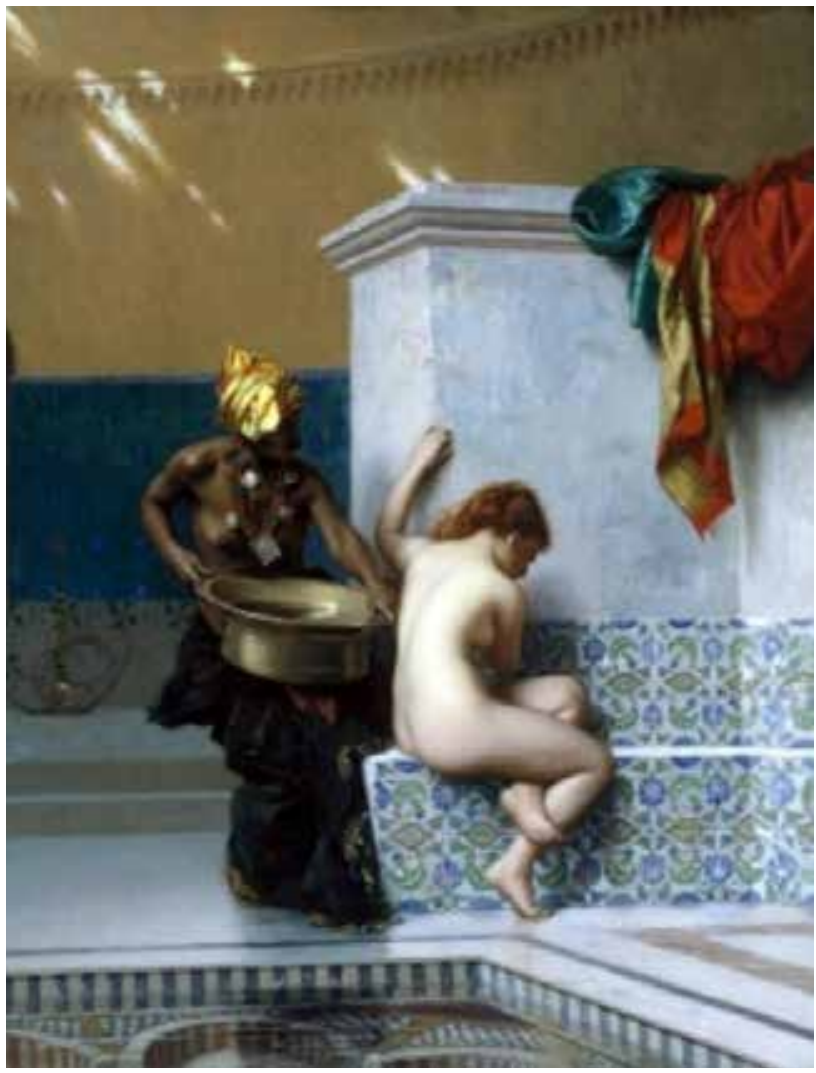

Fonte: Disponivel em: $\leq$ https://commons.wikimedia.org/ wiki/File:Jean-Léon Gérôme - Moorish bath.jpg>. Acesso em: 07 fev. 2017.

Não à toa, este anúncio foi, segundo Paula (2012), objeto de um processo junto ao órgão de regulamentação da publicidade no Brasil, o Conselho Nacional de Autorregulamentação Publicitária (CONAR). É surpreendente que em sua defesa a agência de publicidade tenha argumentado que "a condição de escravo tratada foi num sentido amoroso, e não de escravos em razão da cor" (PAULA, 2012, p. 155). É ainda mais surpreendente que a agência tenha vencido o processo com este argumento, demonstrando a incapacidade do CONAR em reconhecer a relação histórica entre exploração sexual e racial.

\section{A tecnologia como fetiche}

Deve estar claro que a sandália Melissa tornase um fetiche, na medida em que sua adora- 
ção esconde a lógica de sua produção e oculta a falta, a carência, a impossibilidade da satisfação plena do desejo que é de plenitude da identidade. Contudo, a campanha pode servir para pensarmos sobre nossa relação fetichista com outros objetos de consumo. 0 anúncio de Melissa expressa, através da relação boneca/robôs, nossa relação fetichista com máquinas. Quero ressaltar especificamente a relação fetichista seres humanos (narcisos)/ robôs sociais. Em que medida estas máquinas (computadores, celulares, humanoides, androides) funcionam como fetiche para sujeitos narcisistas?

\section{A companhia e o sexo com imagens técnicas de si}

Loverobots destaca-se não só pela representação da mulher como uma boneca de plástico com feições infantis, mas pela representação de um outro robótico atuando como um escravo sexual. De que imaginário, porém, se alimenta essa referência a robôs? Situações de erotismo são há muito utilizadas pela publicidade em estratégias visuais de persuasão. Mas com robôs? Com certo esforço, as imagens de Loverobots, em princípio estranhas, podem aos poucos ser relacionadas a outras tantas imagens de nossa história.

É evidente que todo este imaginário em torno da nossa relação com as máquinas tem como maior provocador a revolução industrial aliada à ascensão social da ciência. Nas fábricas, a regulação do ritmo dos corpos humanos ao movimento de máquinas pode evocar fantasias que seriam impossiveis de se imaginar em períodos prévios - em que porventura devaneamos experiências eróticas distintas, como com seres da natureza ou forças sobrenaturais. Alguns artistas ajudam-nos a lembrar deste aspecto mecanizado de nossa sociedade, na maioria das vezes opostos à aura de glamour conferida a certos produtos em campanhas ou nos totens de grandes lojas. Andreas Gursky lembra-nos, com suas fotografias de galpões industriais, a lógica mecânica e muitas vezes alienada da experiência dos operários envolvidos na produção de objetos de consumo que inundam o mercado global. Com suas esculturas de ciborgues, Fan Xiaoyan faz-nos lembrar que grande parte desses operários, especialmente na China, talvez o polo industrial mais importante para o crescimento da economia mundial, nas últimas décadas, é composto por mulheres. Suas esculturas também trazem uma carga erótica. 0 que me lembra que desde filmes clássicos, como Metrópolis (1927) de Fritz Lang, a experiência erótica entre humanos e robôs sociais é vislumbrada. A fantasia de humanizar de alguma forma tais máquinas vem de longa data. Hoje, ao contrário dos tempos de Metrópolis, já podemos dizer que a era dos robôs sociais começou.

Figura 17 - Siemens, Karlsruhe, Germany (1991), de Andreas Gursky.

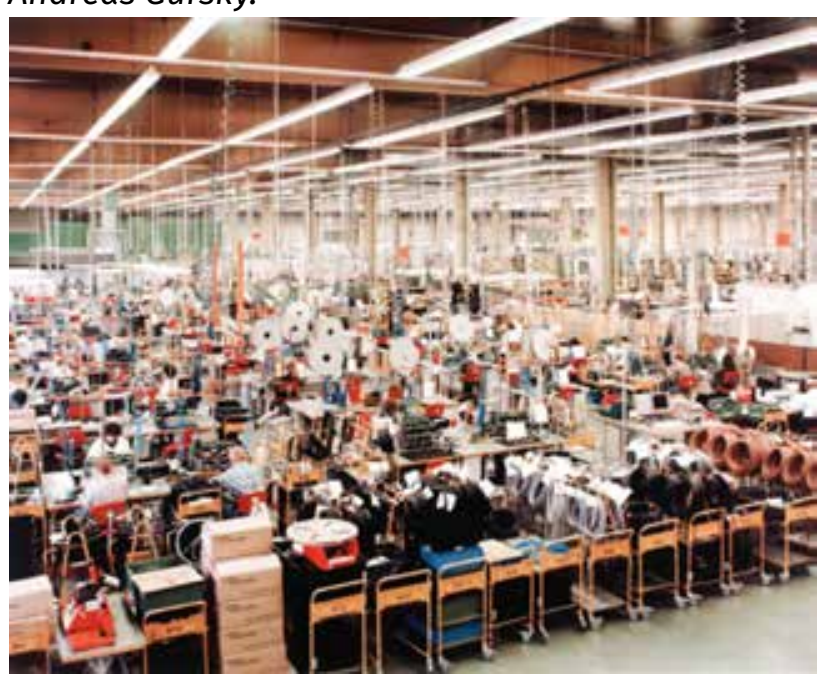

Fonte: Disponivel em: <http://www.fmkorea. com/17846706>. Acesso em: 07 fev. 2017. 
Figura 18 - Cena do filme Metropolis

(1927), de Fritz Lang

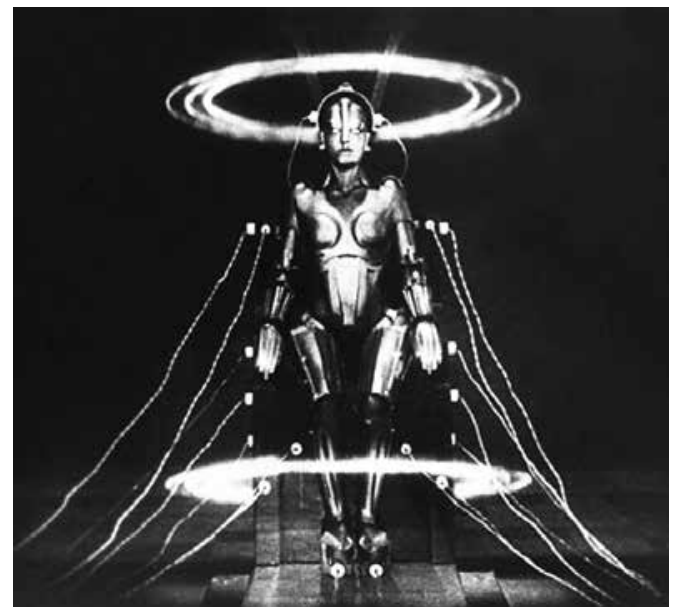

Figura 19 - Physical Attachment - Sculpture no.3 (2008), de Fan Xiaoyan.

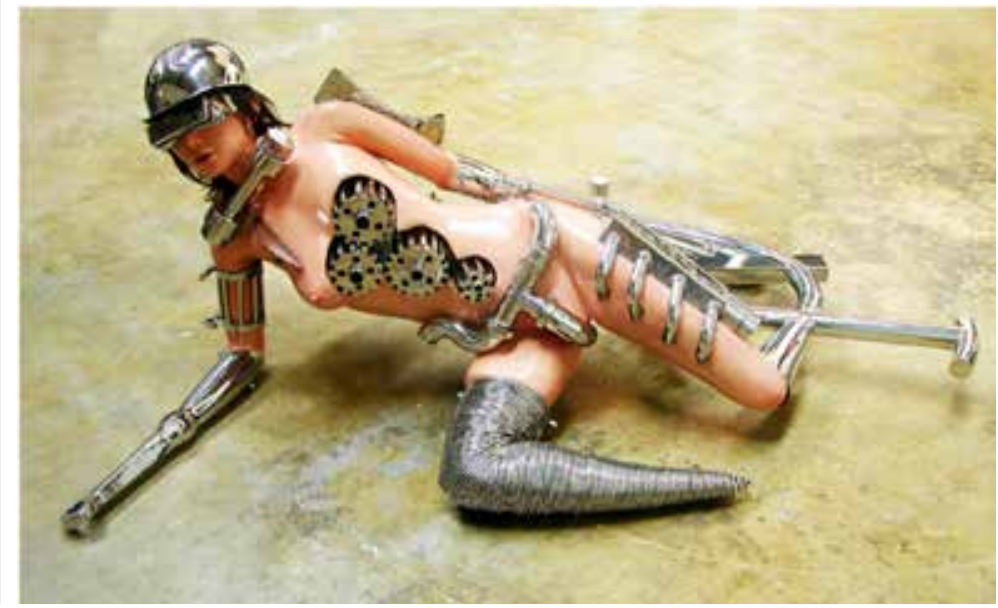

Fonte: Disponivel em: <http://orientalvisart.blog41.fc2.com/blog-entry-77.html>. Acesso em: 07 fev. 2017.

Segundo Turkle (2012), tecnologias ditas sociais, não só os robôs sociais, se tornam atraentes, pois estamos mais vulneráveis, estamos cada vez mais solitários, tendo menos filhos, morando mais só, frequentemente atormentados pela sensação de que ninguém está nos ouvindo. Isolamento, fenômeno que Debord (1997) já descrevia desde os 60 do século passado como fundamental para a relação que estabelecemos para com a máquina televisão. Instrumentos como os robôs sociais representam um desenvolvimento tecnológico, pois nos fazem sentir que estamos sendo ouvidos, parecem se importar conosco. Hoje, robôs sociais, como o Jibo são vendidos como companheiros especialmente para idosos.

Todavia, não é apenas pelo fato de estarmos mais solitários que estas tecnologias nos atraem. Segundo Turkle (2012), apesar de solitários, temos medo da intimidade, não queremos os compromissos e desafios da intimidade. La Taille (2009) defende que este fenómeno é manifestação da tendência contemporânea à efemeridade dos engajamentos. Para ele, "se o imperativo pós-moderno é 'não se fixar', não se fixar em projetos, em valores, em lugares, porque o homem contemporâneo haveria de se fixar em pessoas?" (2009, p. 51). A fraqueza destas ligações estaria associada à necessidade de uma flexibilidade que possibilite fugir dos desprazeres e potencializar as gratificações. Para ele, há “uma maior disposição a conviver com pessoas que não nos façam pensar muito na vida, que não nos aborreçam com questionamentos de dificil solução, que nos proporcionem sensações fortes, momentos de prazer" (2009, p. 63).

Tais robôs sociais, sejam representações mais ou menos abstratas, como esculturas, são imagens, imagens nas quais fantasiamos vida, companhia. Uma ilusão de companhia sem as demandas da amizade/intimidade. Sentimos assim que temos controle e que não seremos provocados quanto a nossas dúvidas e inseguranças. Logo, tais tecnologias não ocupam o lugar de um outro qualquer. Tais soft/hardwares são projetados para espelhar o nosso desejo, mapear e adaptar-se a nossos comportamentos. Tais tecnologias devem refletir-nos, pois devem compreender-nos e disponibilizar apenas o que e como desejamos. Há uma fotografia de David Guttenfelder, de sua coleção The humanoids, que me remete a tal condição. Nesta, um homem senta-se ao lado de um robô com mesmo cabelo, roupa e tamanho. Ao lado dos dois um espelho replica a cena. A projeção narcísica é evidenciada no reflexo duplo, do homem para o humanoide e desta dupla para com sua imagem no espelho. 
Figura 20 - Fotografia de The humanoids, de David Guttenfelder.

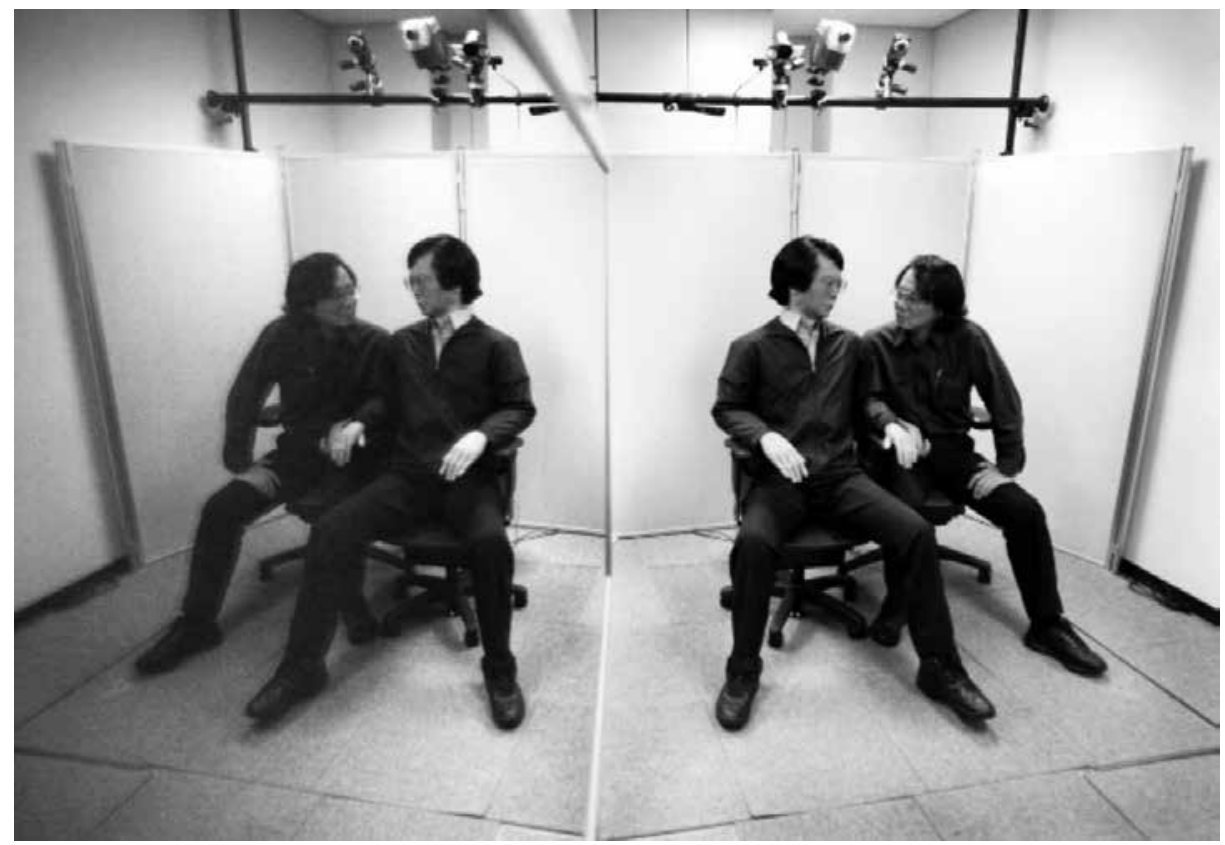

Fonte: Disponivel em: <http://www.davidguttenfelder.com/the-humanoids/>.

Acesso em: 07 fev. 2017.

Proponho que tais robôs sociais podem ser extremamente úteis, portanto, a um sujeito narcisista, na medida em que se oferecem como um outro que tira o sujeito da solidão, ocupam o lugar do outro, mas de um outro especializado em gratificar. Tais máquinas oferecem-se para nossa gratificação, assumem o lugar do outro, assim como deseja o sujeito narcisista, um outro não dotado de autonomia, um outro que existe sob nosso controle e que oferece um reflexo de nós mesmos, desde que deve retornar apenas nossos desejos. Proveem um contato assim como anseia o narcisista. Afinal, como diz Yontef (1998), muito do que passa por contato pessoa a pessoa, para um narcisista "não é contato pessoal, de maneira nenhuma, nem é awareness de seus sentimentos mais profundos" (1998, p. 313), desde que o outro, para o narcisista, é menos um ser com desejos próprios do que um meio para sua gratificação.

Assim, observo o crescente desejo de termos com máquinas, e não com seres humanos, o contato mais íntimo, a sexualidade. É o caso das bonecas robóticas desenvolvidas para serem companheiras sexuais, como as da mar- ca RealDoll. Ao pensar sobre essas máquinas programadas para se adequarem aos nossos anseios, para melhor nos gratificar, como a RealDoll Harmony, o sexo aqui ganha tom de automasturbação. Afinal tratam-se apenas de instrumentos utilizados para chegar ao próprio orgasmo. Estamos acompanhados, mas por um objeto, não há nenhum compromisso com o prazer deste outro.

Ressalto que não é meu interesse profetizar nenhuma moral repressora do autoerotismo, mas levanto, contudo, a importância de pensarmos sobre o aspecto histórico e cultural do modo como vivemos nossa sexualidade, especialmente no que se refere ao fetiche por robôs sociais. Afinal, podem revelar algo mais profundo sobre a sexualidade, em nossa cultura?

Segundo Hooks (2004), há que se destacar que, em nossa cultura patriarcal, o script da sexualidade já associa o desejo por sexo com a ânsia por dominação e poder. Aprendemos que "no mundo das relações sexuais há sempre um dominante e um submisso" (2004, p. 77), e que homens fortes devem estar na posição dominante. A ideia de que a relação sexual 
é uma encenação de poder e dominação leva necessariamente a uma discussão sobre o que homens esperam do sexo. Hooks defende que se trata menos do prazer sensual do contato e mais de convencer-se do lugar de homem. "A sexualidade viciada é fundamentalmente sobre a necessidade de constantemente afirmar e reafirmar individualidade" (2004, p. 82), de confirmar para si mesmo de que sim se é homem, identidade associada a poder. Logo, é possivel concluir que não é estranha a demanda masculina por robôs que ocupem esta figura feminina de submissão. Trata-se apenas de uma manifestação, sim, exacerbada, da re- lação entre sexualidade e a fantasia identitária patriarcal, uma erotização menos do contato sensual com outro ser humano e mais da visão de si como detentor de poder, domínio, controle.

Nesse sentido, a escultura Oh! Charley, Charley, Charley... (1992), de Charles Ray, em que o artista retrata a si mesmo fazendo sexo com múltiplas cópias de si é representativa, portanto, de um erotismo autocentrado, focado antes em si, na própria visão de si, do que no encontro com um outro.

Hooks (2004) define a masculinidade patriarcal como narcisista. É evidente o narcisis-

Figura 21 - Oh! Charley, Charley, Charley... (1992), de Charles Ray.

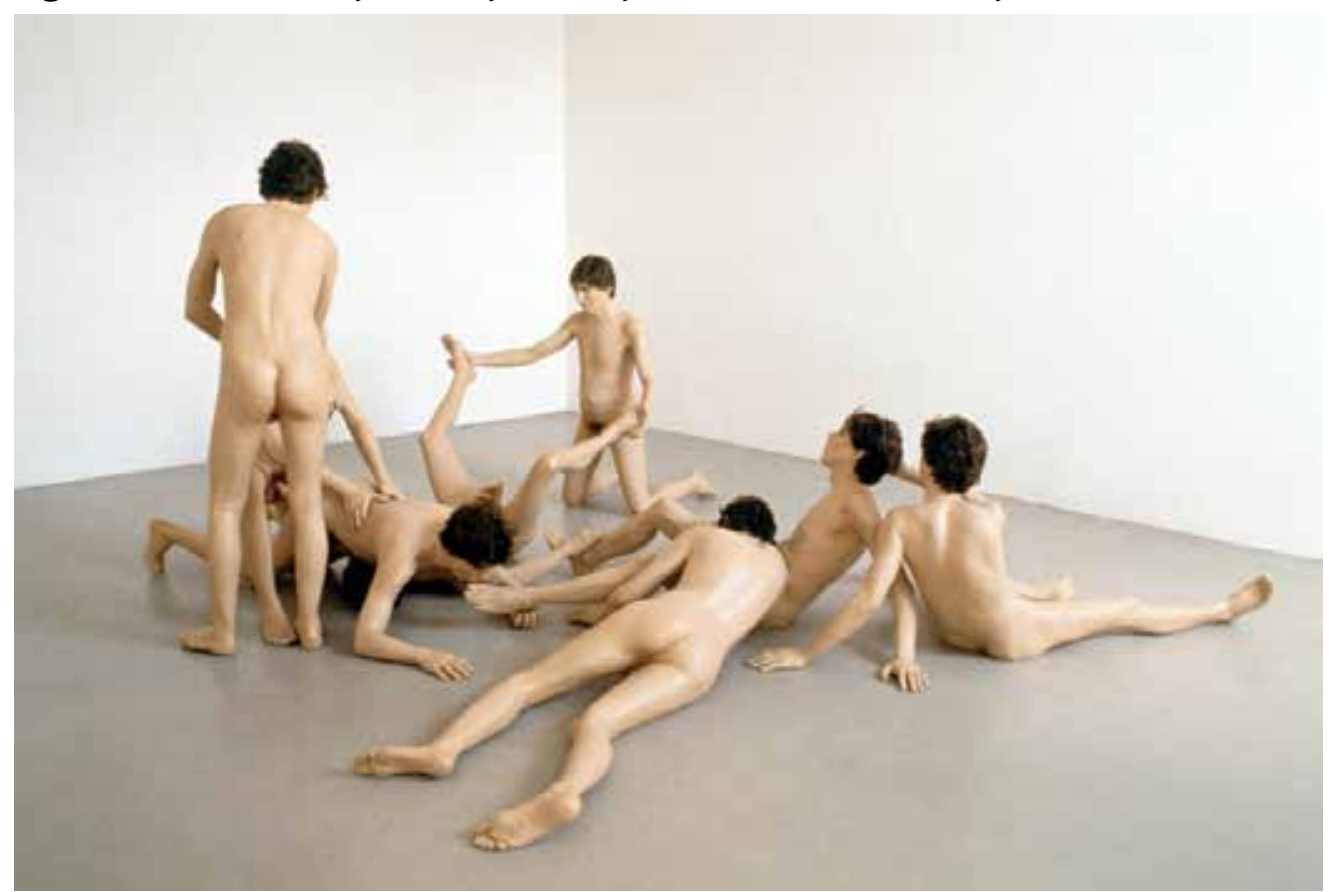

Fonte: Disponivel em: <https://www.charlesraysculpture.com/collections/oh-charley-charley-charley/>. Acesso em: 07 fev. 2017.

mo nesta demanda por satisfação, pela confirmação de uma imagem de si idealizada. No final, o circuito acaba por se fechar no desejo de encontrar a si mesmo, de experimentar a ilusão de plenitude.

\section{Controlar e ser controlad"A"}

Assistir filmes como Ela (2014), de Spike Jonze, e Ex-machina (2015), de Alex Garland, pode promover insights que ajudam a pensar Melissa Loverobots desde que, como espero defender a seguir, são meditações sobre o uso narcisista de tecnologias sociais. Ex Machina conta a história de Nathan, empresário/cientista que desenvolve Ava, “uma” robô, e convoca Caleb, um funcionário, para conviver com ela durante uma semana. Ela conta a história de Theodore, homem com dificuldades em relacionar-se e 
que acaba por apaixonar-se por Samantha, um sistema operacional. Estes filmes interessam, pois ajudam a discutir a aparente fronteira humanos/máquinas. 0 que há de mecânico nestes homens, o que há de humanidade nestas máquinas? Se as máquinas querem ser seres humanos, querem os seres humanos ser máquinas?

Quem são afinal essas máquinas projetadas para serem como nós? Em Ex machina, Ava é projetada para refletir a imagem do ser humano, assim como a imagina Nathan, megamilionário do ramo da tecnologia. Ava, que aparentemente deveria ser apenas uma escrava da vontade de seu dono, revela sua mais profunda programação, ao final do filme. Após seduzir Caleb a ajudá-la a escapar de Nathan, abandona Caleb e deixa-o preso. Ela não passa de uma máquina de persuasão. Não é à toa que, como diz Nathan, sua inteligência se baseie em um sistema de busca - lembro que sites como Google dependem financeiramente da sua capacidade de promoverem seus anunciantes. Em Ex machina, o interesse próprio vence qualquer expectativa de altruísmo. Ava é a representação do indivíduo descrito pelos filósofos e economistas neoliberais, pois relaciona-se com outros como se estivesse em um jogo pautado no interesse próprio (LAGASNERIE, 2013). A sociabilidade não passaria de uma disputa em que todos concorrem com todos e na qual o vencedor será o maior traidor e manipulador.

Já Samantha, em Ela, um sistema operacional, aos poucos desenvolve o mesmo desejo de Theodore, seu dono, desejo por novas sensações de prazer, sua insatisfação. Ele queria que ela simplesmente satisfizesse seus anseios, mas logo perde o controle sobre o que ela experimenta, com quem ela está em contato e quem ela está a se tornar. O filme termina com Theodore dando-se conta de que não tem domínio sobre Samantha. Limitar-se a corresponder aos desejos de Theodore torna-se logo um empecilho aos de Samantha. Ela acaba por mimetizar a busca fetichista de Theodore pelo "mais gozar". Pode-se concluir assim que tanto Ava quanto Samantha representam formas contemporâneas de ser humano.

Por outro lado, em vários momentos do filme Theodore é acusado de não saber lidar com seres humanos reais, com suas emoções reais. Não seria esta uma acusação digna de ser feita a um robô? É curioso que pessoas contratem Theodore justamente para que escreva profissionalmente por elas belas cartas, repletas de sentimentos, para parentes ou amantes. Como ele próprio (assim diz sua vida pessoal), estas pessoas parecem inaptas a relacionar-se com outras.

Por sua vez, Nathan usa Caleb e Ava sem expressar nenhum tipo de empatia pelo que causa a eles. Para ele, os dois não passam de ratos em um experimento. Ava é menos uma imagem de um ser humano qualquer e mais uma imagem do próprio Nathan, manipulador, calculista. Como o próprio Nathan defende, saber-se-ia que Ava pode passar por humana, não tanto por ela ter consciência de que tem emoções, mas por fingir emoções para conseguir o que quer.

Como vimos, o narcisismo é uma condição psicológica mais complexa do que costumamos supor. Neste sentido, proponho que enquanto Nathan, em Ex Machina, representa a versão arrogante do narcisista, Theodore, em Ela, expressa o polo francamente carente e frágil, encarna o sujeito moderno solitário e inapto a conviver com a falta de controle sob os desejos daquelas com quem se relaciona. Ambos, contudo, representam facetas do que se esperaria de robôs, a falta de empatia ou a dificuldade de lidar com as emoções alheias.

Ao perceber aspectos maquínicos nos humanos e não apenas aspectos humanos nas máquinas, pude então revisitar minha análise de sexualidade e gênero em Melissa Loverobots. 
A sexualização da relação entre humanos e tecnologia é evidente nos dois filmes. As principais cenas de Ela mostram o desenvolvimento de uma vida sexual entre Theodore e Samanta. Em uma cena bastante complexa, Samanta, o sistema operacional, recorre a Isabela, uma mulher, utiliza-se de seu corpo como se fosse um avatar, do qual toma posse, para assim poder encenar uma interação carnal com Theodore. A dinâmica acaba por ser um fracasso, contudo é extremamente significante por demonstrar o interesse de Isabela em ceder sua agência para uma máquina. É mais um ponto do filme em que podemos nos perguntar sobre as supostas fronteiras entre a humanidade e as tecnologias que esta criou para si.

Figura 22 - Cena do filme Ela (2014), de Spike Jonze - Theodore e Isabela.

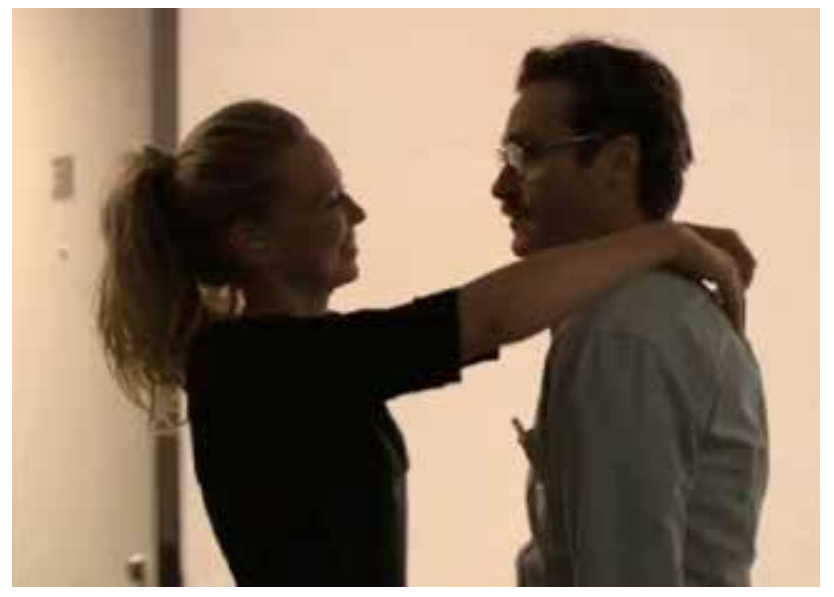

Talvez este desejo de existir menos como ser dotado de emoções e mais como uma máquina, faça-nos reforçar a associação simbólica entre robôs e bonecas, e não apenas as diferenças, para assim melhor compreender os desejos evocados em Melissa Loverobots. Penso em uma das cenas mais impactantes de Ex Machina, aquela em que Caleb encontra no quarto de Nathan, dispostos diante de sua cama, caixas cujas portas são espelhos. Do outro lado das portas-espelho, ele encontra outro tipo de reflexo, vários robôs, humanoides. No quarto, ele também encontra Kyoko, a amante de Nathan, deitada na cama. Ela arran- ca a própria pele e confirma que robô, boneca e escrava sexual são um único ser.

Figura 23 - Cena do filme Ex Machina (2015), de Alex Garland - Caleb e Kyoko.

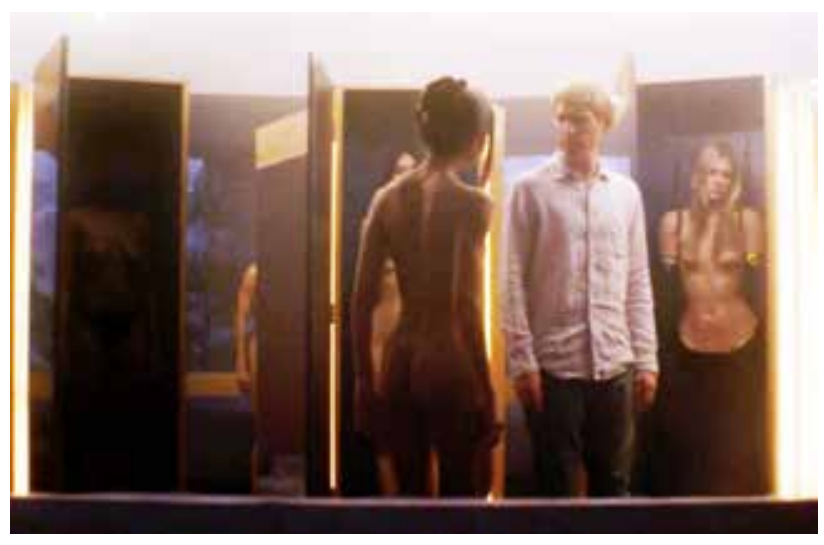

Por um lado, Loverobots alimenta-se do desejo de ter a disposição um escravo sexual, um ser que friamente temos sob controle, como querem Nathan e Theodore. Contudo, por tudo acima, questiono-me se o anúncio não se alimenta também do desejo de tornarse um ser sem agência, como escolhe Isabela em Her. Afinal, uma boneca é, tanto quanto um robô, uma imagem e, destaco, um objeto. Esta interpretação se reforça especialmente nos anúncios 1 e 3 , desde que nos dois é a boneca que parece estar sob o controle do robô, não o contrário. No primeiro, a boneca deitada está presa por vários braços, no terceiro, um robô gigante a traz para sua boca, como se fosse engoli-la. Relações racistas podem estar em jogo, somando-se às de gênero, já que o anúncio 2, o único em que os robôs são claramente submissos, é o único com robôs negros.

Pensando assim, a própria mulher consumidora que se identifica com a posição da boneca tornar-se-ia a fetichista, mas também o fetiche, o objeto para o controle de um outro? A consumidora que se identifica com a figura da boneca não está, como Isabela, organizando também suas fantasias em torno da abdicação da própria agência? Aqui voltaríamos a nos enfrentar com as tradicionais posições de gênero tão denunciadas por Hooks (2004). Por 
mais que Melissa Loverobots em seu título defina a figura masculina do robô com o escravo, as imagens contêm uma ambiguidade em relação a quem está objetificado por quem.

\section{Redes sociais: o espelho (editado) que confirma a existência (ideal)}

Acredito que é possivel abstrairmos um pouco mais o debate até aqui centrado na figura do robô social, se imaginarmos que a imagem do robô em Melissa Loverobots pode funcionar também como metáfora para nossa relação com outras tecnologias sociais. Esta ideia me surge especialmente quando penso sobre o anúncio em que a boneca olha nos olhos do robô. Penso sobre o desejo narcisista de ser visto, e de se ver sendo visto, tão usual nas redes sociais.

Turkle (2012) aponta a crescente dificuldade de ficarmos sós, ficamos ansiosos, inquietos, entramos em pânico. Estar sozinho parece ser um problema que precisa ser resolvido e tentamos resolver com conexão. Para La Taille (2009, p. 74), a angústia por conexão é apenas uma das formas da "frenética busca de ocupar a todo instante o tempo" que acomete muitos de nós na pós-modernidade. Segundo este autor, trata-se de um indício (assim como o crescimento dos números de suicídio e depressão) do que descreve como cultura do tédio, em que estamos a todo momento sujeitos a nos confrontar com o vazio de sentido, de direção e significado, que nossa forma de sociabilidade falha em prover.

Por outro lado, segundo Turkle (2012), a conexão é mais sintoma do que cura de um problema, desde que demonstra a necessidade constante de reafirmar para si, através da visão da imagem de si, de que sim nós existimos. Como diz Sibilia (2012, p. 169):

As redes sociais, assim como os reality shows, por exemplo, ensinam e permitem consumar o anseio de ser vigiado ou, em termos mais exatos, visualmente consumido. Por isso, se a subjetividade contemporânea se torna 'controlada', isso não se dá como efeito de um panóptico externo que vigia e normaliza todos os cidadãos sob o peso moral da lei, mas pela ameaça de exclusão - ou até de inexistência - que pode ser provocada pela falta de alguém que (me) olhe. Volta à tona aqui o já citado pavor de 'virar um nada', que pode ser particularmente atroz quando o que se é não se baseia na própria interioridade, mas se constrói na visibilidade dos corpos e das telas.

Embora Sibilia (2012) não se debruce sobre o narcisismo, ficam evidentes as relações com os sujeitos a que se refere. Como descreve Yontef (1998, p. 315), "os pacientes narcisistas, com frequência, sentem-se invisíveis". Sem olhares de admiração, vivenciam a sensação de nada ser. "Elas se sentem depletadas, como que vazias por dentro - como se 'não tivessem self'" (1998, p. 316).

É neste sentido que tecnologias como as redes sociais ganham centralidade aqui. Para Turkle (2012), a conexão constante está transformando a forma como as pessoas pensam a si mesmas. Se não temos conexão, não nos sentimos nós mesmos. Aqui também percebese que a conexão com o outro pode vir a ter como função maior, menos debruçar-se sobre sua diferença radical, e mais o encontrar e reafirmar a si próprio.

A vantagem da rede, como um espelho que confirma nossa existência, é que melhor nos permite apresentar o self como queríamos que fosse, editamos, deletamos, retocamos. Este ponto é o tema do irreverente curta What is on your mind (2014), de Andrew Higton, ao qual associo a cena de troca de olhares no anúncio Loverobots, em que a boneca encara o robô que retorna o olhar.

\section{Contra a dupla alienação}

Diante do caminho narcisista, da dependência em relação a uma imagem ideal de si, da dupla 
alienação que implica, do sujeito para consigo e para com o outro, ressalto a importância de uma educação da cultura visual e um ensino de artes que promovam experiências pedagógicas que contribuam para a maior capacidade de estarmos sós conosco, de lidarmos

\section{Referências}

AGUIRRE, I. Cultura visual, política da estética e educação emancipadora. In: MARTINS, R.; TOURINHO, I. (Orgs.). Educação da cultura visual: conceitos e contextos. Santa Maria: Editora da UFSM, 2011. p. 69-112.

ARGAN, G. C. Imagem e persuasão: ensaios sobre o barroco. São Paulo: Companhia das Letras, 2004.

BAUDRILLARD, J. Simulacros e simulações. Lisboa: Relógio D’Água, 1991.

BERGER, J. Modos de ver. Rio de Janeiro: Rocco, 1999.

KEHL, M. R. Fetichismo. In: BUCCI, E.; KEHL, M. R. (Orgs.). Videologias. São Paulo: Boitempo, 2004a. p. 63-86

Visibilidade e espetáculo. In: BUCCI, E.; KEHL, M. R. (Orgs.). Videologias. São Paulo: Boitempo, 2004b. p. 141-164.

\section{CAMPBELL, C. Ética romântica e o espírito do consu-} mismo moderno. Rio de Janeiro: Rocco, 2001.

DEBORD, G. A sociedade do espetáculo. Rio de Janeiro: Contraponto, 1997.

ELA. Direção: Spike Jonze. [S.l.]: Sony Pictures, 2014. 1 DVD (126 min), NTSC, color. Título original: Her.

ELIAS, N. A sociedade dos indivíduos. Rio de Janeiro: Jorge Zahar Editor, 1994.

ESTEVAM, J. G. O reconhecimento da alteridade como possibilidade de construção de um novo paradigma na cultura ocidental em Joel Birman e Emmanuel Lévinas. Horizonte, Belo Horizonte, v. 6, n. 12, p. 169179, jun. 2008.

EX_MACHINA: Inteligência artificial. Direção: Alex Garland. [S.l.]: Universal Pictures, 2015. 1 DVD (110 min), NTSC, color. Título original: Ex_Machina. com nossas carências, e também de estarmos juntos, uns com os outros, e de lidarmos com nossas diferenças. Tratam-se de objetivos que deveriam sempre estar entre os maiores desafios das práticas educacionais, mas que nem sempre são lembrados.

GALVÃO, B. A. A ética em Michael Foucault: do cuidado de si à estética da existência. Intuitio, Porto Alegre, v. 7, n. 1, p. 157-168, Junho 2014.

HERNANDEZ, F. A cultura visual como um convite à deslocalização do olhar e ao reposicionamento do sujeito. In: MARTINS, R.; TOURINHO, I. (Orgs.). Educação da cultura visual: conceitos e contextos. Santa Maria: Editora da UFSM, 2011. p. 31-49.

HOOKS, B. The will to change: men, masculinity, and love. New York: Atria books, 2004.

KELLNER, D. A cultura da mídia. Bauru, SP: EDUSC, 2001.

LA TAILLE, Y. D. Formação ética: do tédio ao respeito de si. Porto Alegre: Artmed, 2009.

LAGASNERIE, G. D. A última lição de Michel Foucault: sobre o neoliberalismo, a teoria e a política. São Paulo: Três Estrelas, 2013.

MACHADO, A. O sujeito na tela. São Paulo: Paulus, 2007.

MANCEBO, D. Modernidade e produção de subjetividades: breve percurso histórico. Psicologia: ciência e profissão [on-line], Brasília, v. 22, n. 1, p. 100-111, mar. 2002.

MARTINS, R. A cultura visual e a construção social da arte, da imagem e das práticas do ver. In: OLIVEIRA, M. O. D. (Org.). Arte, educação e cultura. Santa Maria: Editora UFSM, 2007. p. 19-40.

MESQUITA, C. Moda contemporânea. São Paulo: Anhembi Morumbi, 2004.

MITCHELL, W. J. T. Showing seeing: a critique of visual culture. Jornal of visual culture, v. 1, n. 2, p. 165181, 2002. 
MULVEY, L. Prazer visual e cinema narrativo. In: MACEDO, A. G.; RAYNER, F. Género, cultura visual e performance. Minho: Edições Húmus, 2011. p. 121-132.

O'DONOHUE, W.; FOWLER, K. A.; LILIENFELD, S. O. Transtorno de personalidade. São Paulo: Roca, 2010. OKSALA, J. Como ler Foucault. Rio de Janeito: Zahar, 2011.

PAULA, M. B. D. Discriminação racial publicitária: apontamentos dos julgados do conselho nacional de autoregulamentação publicitária (CONAR). 2012. 217 f. Dissertação (Mestrado em Direito) - Fundação Getúlio Vargas, São Paulo, 2012.

PORTUGAL, D. B. A vinculação entre humanos e imagens nas dinâmicas contemporâneas do consumo: totemismo, fetichismo e idolatria. Estudos em design, v. 19, p. 1-18, 2011.

SAMAIN, E. As "Mnemosyne(s)" de Aby Warburg: entre Antropologia, Imagens e Arte. Revista Poiésis, n. 17, p. 29-51, julho 2011.

SIBILIA, P. Redes ou paredes: a escola em tempos de dispersão. Rio de Janeiro: Contraponto, 2012.

STURKEN, M.; CARTWRIGHT, L. Practices of looking: an introduction to visual culture. New York: Oxford University Press, 2001.

TURKLE, S. Alone together: why we expect more from technology and less from each other. New York: Basic Books, 2012.

WOLFF, F. Por trás do espetáculo: o poder das imagens. In: NOVAES, A. Muito além do espetáculo. São Paulo: Editora Senac, 2005. p. 16-45.

YONTEF, G. M. Processo, diálogo, awareness. São Paulo: Summus, 1998.

ZANA, A. R. D. O.; PERELSON, S. A devoração do objeto associada ao imperativo de satisfação plena: 0 que poderia a psicanálise diante dos novos modos de (não) relação com a alteridade? In: CONGRESSO INTERNACIONAL DE PSICOPATOLOGIA FUNDAMENTAL, 5., 2012, Fortaleza. Anais... Fortaleza: [s.n.], 2012.

Recebido em: 10.02.2017

Aprovado em: 04.04.2017

Pablo Petit Passos Sérvio é doutor em Arte e Cultura Visual pelo Programa de Pós-graduação em Arte e Cultura Visual da Universidade Federal de Goiás e professor do Departamento de Artes da Universidade Federal do Maranhão - UFMA. Telefone institucional: 98 3272-8324. e-mail:pservio@gmail.com

Departamento de Artes (DEART) - Centro de Ciências Humanas (CCH) - Av. dos Portugueses, 1966. Bacanga. São Luís/ MA. CEP 65.080-805. 